\title{
THE RELATIONSHIP BETWEEN STRUCTURE AND PERFORMANCE OF OPEN SOURCE PROJECTS: CASE OF LEARNING CONTENT MANAGEMENT SYSTEMS
}

\author{
by \\ Piedad Bibiana Pinzón \\ A thesis submitted to the Faculty of Graduate Studies and Research \\ in partial fulfillment of the requirements for the degree of \\ Master of Engineering in Telecommunications Technology Management
}

\author{
Department of Systems and Computer Engineering \\ Carleton University \\ Ottawa, Canada, K1S 5B6
}

January, 2006

C Copyright 2006 Piedad Bibiana Pinzón 


$\begin{array}{ll}\begin{array}{l}\text { Library and } \\ \text { Archives Canada }\end{array} & \begin{array}{l}\text { Bibliothèque et } \\ \text { Archives Canada }\end{array} \\ \begin{array}{l}\text { Published Heritage } \\ \text { Branch }\end{array} & \begin{array}{l}\text { Direction du } \\ \text { Patrimoine de l'édition }\end{array} \\ \begin{array}{l}\text { 395 Wellington Street } \\ \text { Ottawa ON K1A ON4 }\end{array} & \begin{array}{l}\text { 395, rue Wellington } \\ \text { Ottawa ON K1A ON4 } \\ \text { Canada }\end{array}\end{array}$

Your file Votre référence ISBN: 978-0-494-16485-3 Our file Notre référence ISBN: 978-0-494-16485-3

NOTICE:

The author has granted a nonexclusive license allowing Library and Archives Canada to reproduce, publish, archive, preserve, conserve, communicate to the public by telecommunication or on the Internet, loan, distribute and sell theses worldwide, for commercial or noncommercial purposes, in microform, paper, electronic and/or any other formats.

The author retains copyright ownership and moral rights in this thesis. Neither the thesis nor substantial extracts from it may be printed or otherwise reproduced without the author's permission.
AVIS:

L'auteur a accordé une licence non exclusive permettant à la Bibliothèque et Archives Canada de reproduire, publier, archiver, sauvegarder, conserver, transmettre au public par télécommunication ou par l'Internet, prêter, distribuer et vendre des thèses partout dans le monde, à des fins commerciales ou autres, sur support microforme, papier, électronique et/ou autres formats.

L'auteur conserve la propriété du droit d'auteur et des droits moraux qui protège cette thèse. $\mathrm{Ni}$ la thèse ni des extraits substantiels de celle-ci ne doivent être imprimés ou autrement reproduits sans son autorisation.
In compliance with the Canadian

Privacy Act some supporting forms may have been removed from this thesis.

While these forms may be included in the document page count, their removal does not represent any loss of content from the thesis.
Conformément à la loi canadienne sur la protection de la vie privée, quelques formulaires secondaires ont été enlevés de cette thèse.

Bien que ces formulaires aient inclus dans la pagination, il n'y aura aucun contenu manquant.

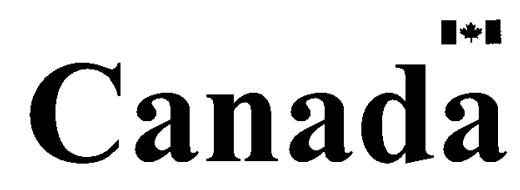




\section{ABSTRACT}

This research uses two perspectives, the communities of practice and sectoral systems of innovation, to examine the relationship between structure and performance of 12 open source projects that develop learning content management systems. The results suggests that: $i$. the structure of an open source project can be operationalized in terms of the location of the development team (concentrated and distributed) and the role where leadership is located (project manager, community leader, and Board); ii. open source projects with a distributed development team led by community leaders perform better than other open source projects; and iii. the communities of practice perspective can be used to examine open source projects. The outcomes of this research include write ups on open source projects that develop learning content management systems, insights on the structure-performance relationship for open source projects, propositions, and a set of variables that may lead to increased performance of open source projects. 


\section{ACKNOWLEDGEMENT}

This thesis was developed as part of the Competing in open environments research program led by Antonio J. Bailetti, from Carleton University, and Peter Carbone, from Nortel. The support received from Nortel and the Telecommunications Technology Management program for this research is gratefully acknowledged.

The way this thesis started was with a reading of "The Art of Fieldwork" by H. Wolcott (1995). He refers that when Michelangelo was asked to describe how he carved the magnificent David, the artist said, "I took a block of stone and chipped away everything that was not David" (Wolcott, 1995).

First, I would like to thank Antonio J. Bailetti, my thesis supervisor, for explaining me the difference between a Master thesis and anything else.

Second, thanks to my fiancée, Hamid, for his charming ability of being patient, caring and tolerant.

Third, thanks to my family in my home country, who at this point must be celebrating the culmination of a dream and the beginning of a new one.

Finally, to the friends of my heart: Mauricio, Diana, Milton, Adriana, Rafael, Carlos, Germán, Darío, Elkin, Sanjay, Avid, Masao, Masood and Ishfaq, who anywhere in the world are also rejoicing in our pride of being together in spite of the distance. 


\section{TABLE OF CONTENTS}

ABSTRACT ............................................................................................................... ii

ACKNOWLEDGEMENT ................................................................................. iv

LIST OF TABLES ........................................................................................... vii

LIST OF FIGURES............................................................................................. viii

GLOSSARY ..................................................................................................... ix

1. INTRODUCTION ...............................................................................................10

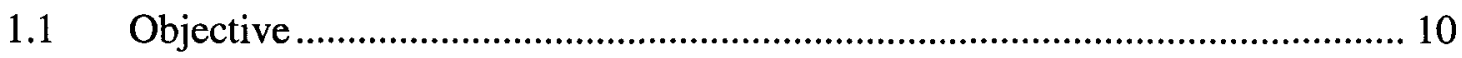

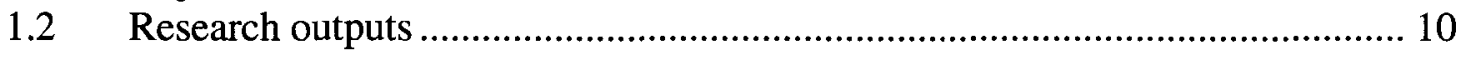

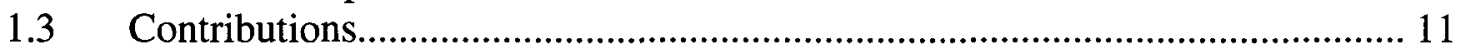

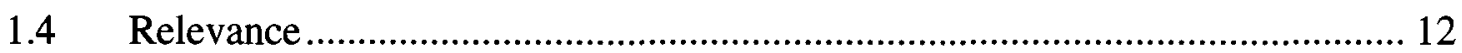

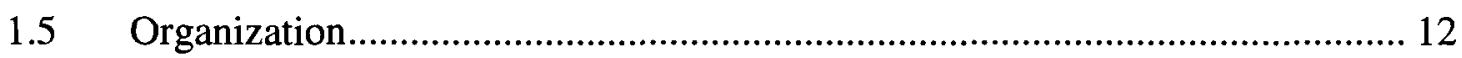

2. LITERATURE REVIEW ................................................................................13

2.1 Learning content management systems ................................................................. 13

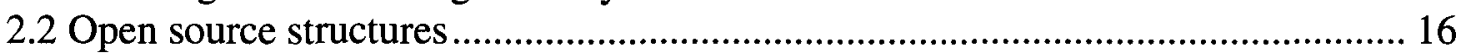

2.3 Theoretical perspectives that will guide the generation of insights and propositions

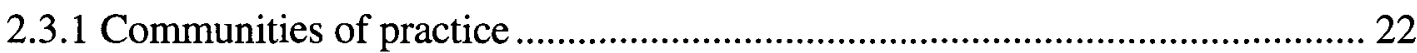

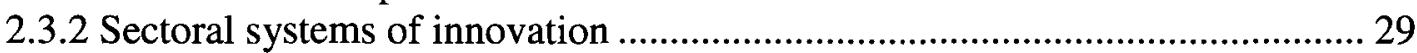

2.4 Lessons learned ................................................................................................... 34

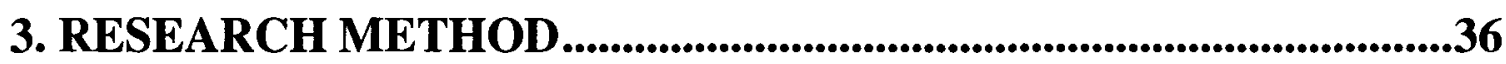

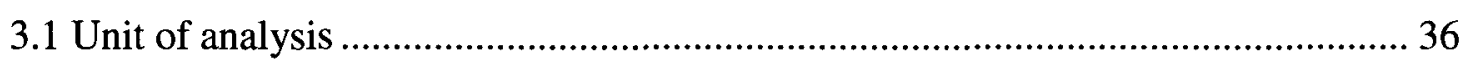

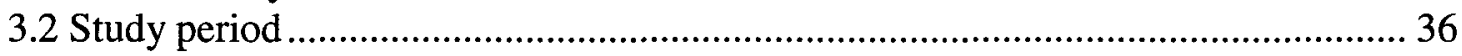

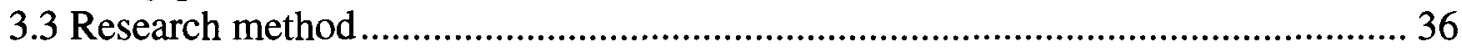

3.3.1 Research model .................................................................................. 38

3.3.2 Rationale for using the two theoretical perspectives ........................................ 39

3.3.3 Constructs selected from theoretical perspectives .......................................... 40

3.3.4 Sample selection .......................................................................................... 40

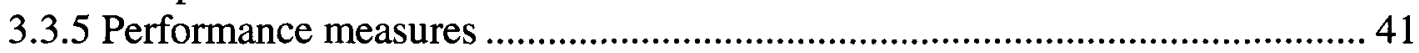

3.3.6 Operationalizing the constructs...................................................................... 42

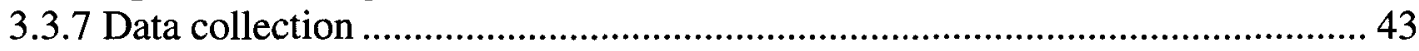

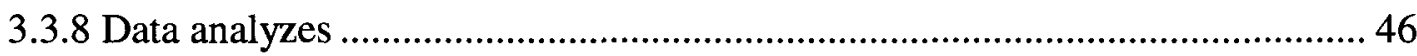

4. SAMPLE AND DATA

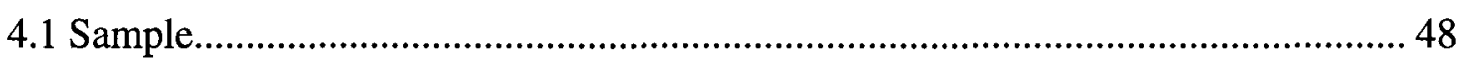

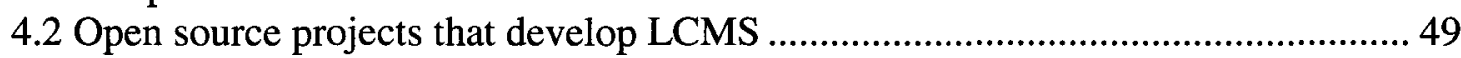

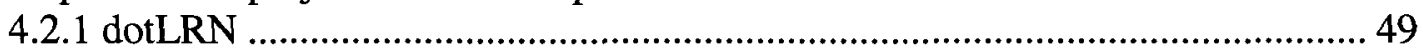

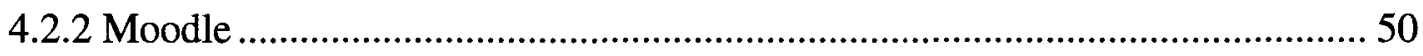




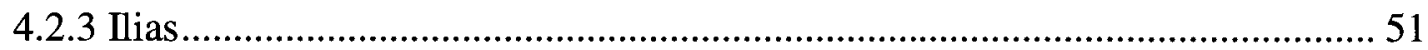

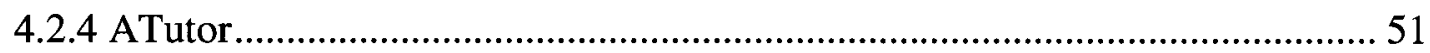

4.2.5 Claroline

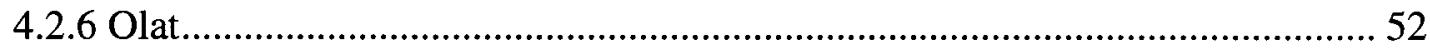

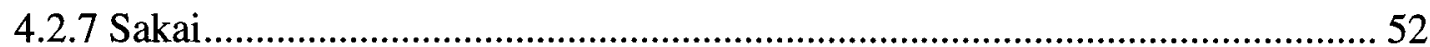

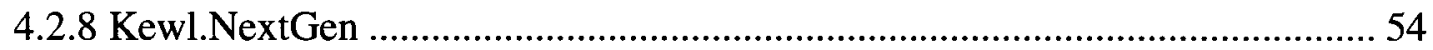

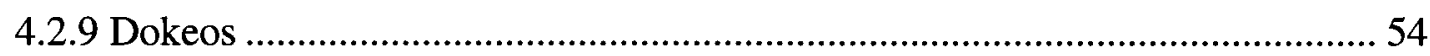

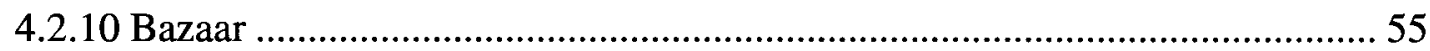

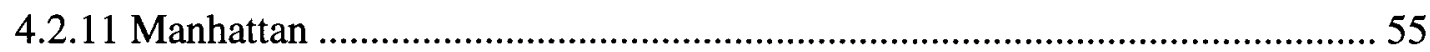

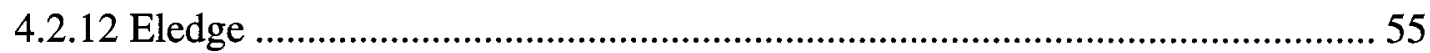

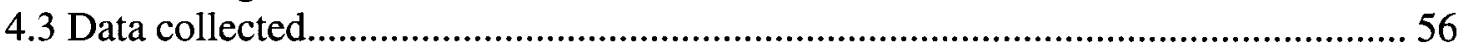

4.4 Using the constructs of two perspectives to examine open source projects

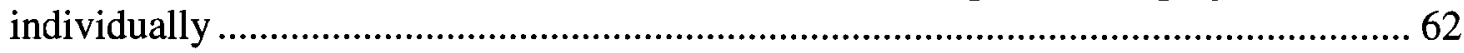

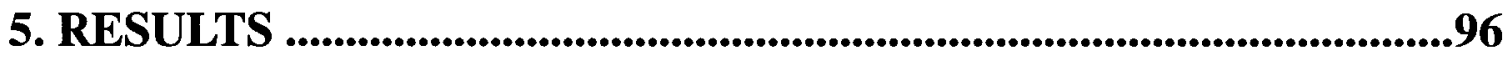

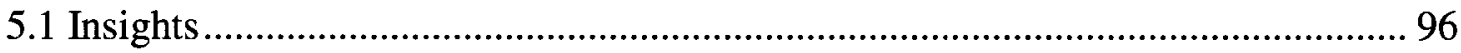

5.2 Propositions that link structure and performance of open source projects ........... 103 5.3 Variables that can be used to assess the performance of a structure developing open

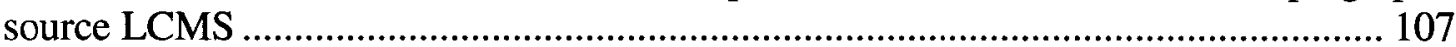

\section{CONCLUSIONS, RECOMMENDATIONS, LIMITATIONS AND SUGGESTIONS FOR FUTURE RESEARCH ..............................................109}

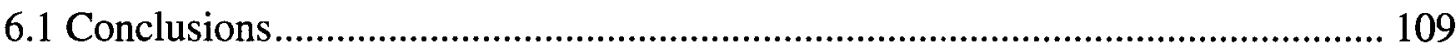

6.2 Recommendations for setting up OSS projects ................................................. 111

6.3 Suggestions to improve the performance of open source projects ....................... 111

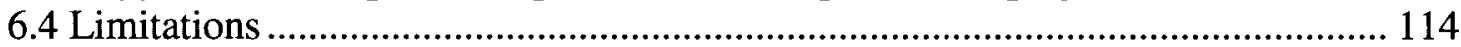

6.5 Suggestions for future research............................................................... 114

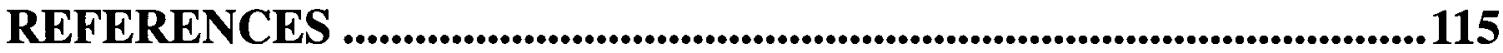




\section{LIST OF TABLES}

Table 1. Structure of an open source community ..................................................... 20

Table 2. Structure from the perspective of community of practice .............................. 28

Table 3. Structure from the perspective of sectoral systems of innovation ..................... 33

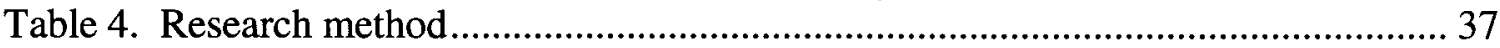

Table 5. Data used to operationalize constructs...................................................... 42

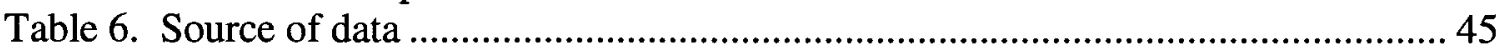

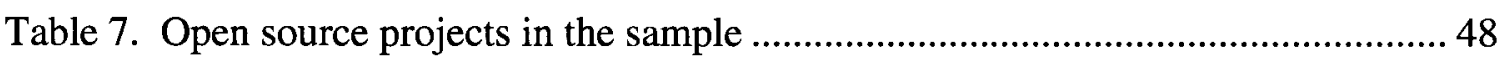

Table 8. Data collected for open source projects ..................................................... 57

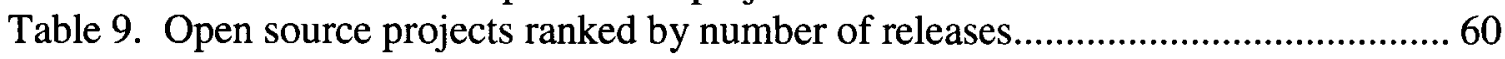

Table 10. Open source projects ranked by number of users / downloads.........................61

Table 11. Open source projects ranked by number of developers ..................................62

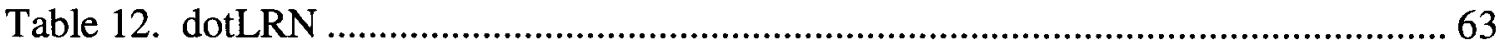

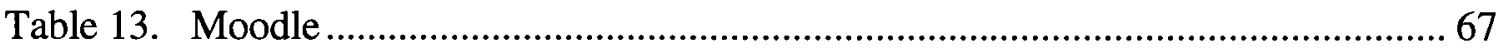

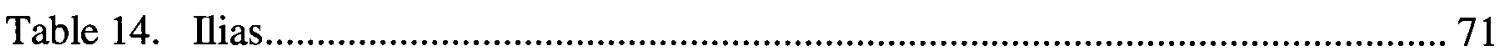

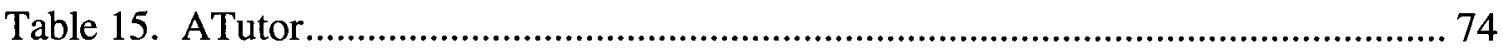

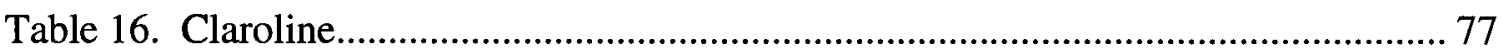

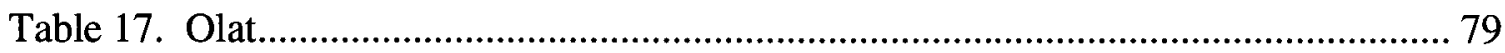

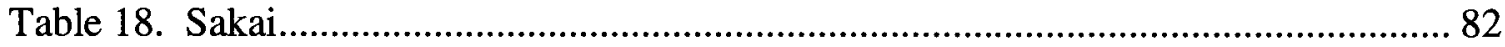

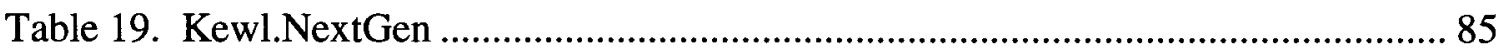

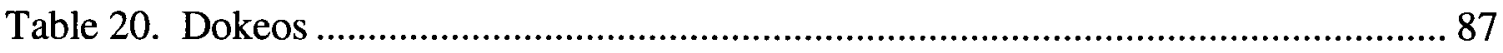

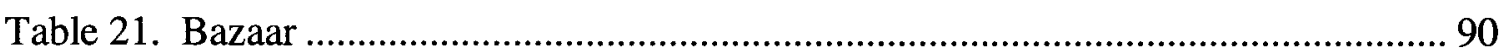

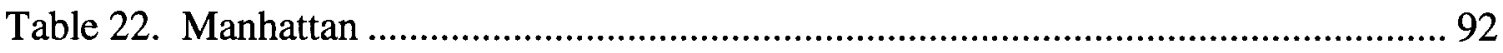

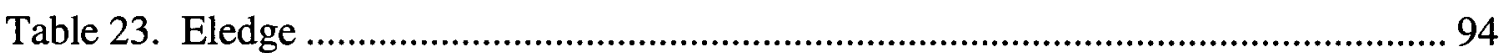

Table 24. Open source projects developing LCMS categorized by location of the core

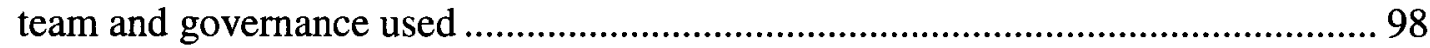

Table 25. Structure - performance of open source projects .................................... 103

Table 26. Factors that increase the likelihood of open source project success............ 112 


\section{LIST OF FIGURES}

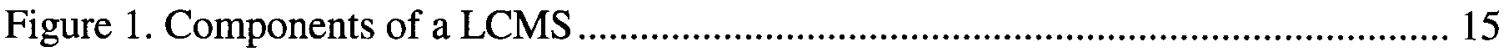

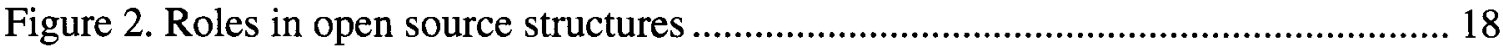

Figure 3. Building blocks of a community of practice ................................................ 24

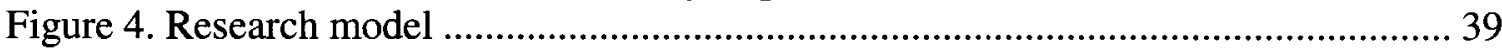

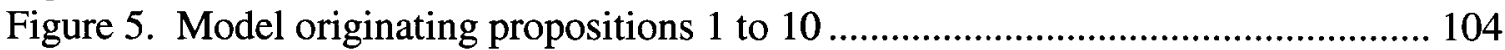

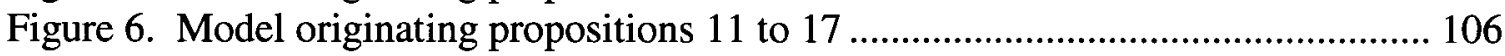




\section{GLOSSARY}

CVS Concurrent versioning system

FAQ Frequently asked questions

GPL General public license

IMS-CP IMS content package

IMS-QTI IMS question and test interoperability

LCMS Learning content management systems

MySQL Multithreaded, multi-user, structured query language

OKI Open knowledge initiative

OSS Open source software

SCORM Sharable content object reference model

XML Extensive markup language 


\section{INTRODUCTION}

\subsection{Objective}

The objective of this research is to examine the relationship between the structure of a project that develops open source software and the project's performance measured as the number of releases per year, number of downloads, and number of developers that contribute to the project.

Data on twelve learning content management systems is used to examine the structureperformance relationships of open source projects. A learning content management system (LCMS) is an enterprise software used to manage the flow of content from a central repository to users along learner paths created by individual profiles and tied to business processes and performance improvement (Donnello, 2002). An LCMS is used to create, store, assemble, and deliver personalized content in the form of learning objects $^{1}$.

\subsection{Research outputs}

The outputs of this research are:

- Write-ups on twelve open source projects that develop LCMS

- Insights gained from examining the structure-performance relationship of twelve LCMS using constructs from two theoretical perspectives, communities of

\footnotetext{
${ }^{1}$ A learning object is a standing piece of education that contains content based on specific learning objectives and that has descriptive metadata wrapped around it (Brennan, Funke and Anderson, 2001). Video clips, illustrations, quiz questions, even course modules are all examples of learning objects.
} 
practice and systems of innovation

- Propositions anchored around a model of the relationship between structure and performance relevant to open source software projects

- Variables that can be used to assess the performance of open source projects

\subsection{Contributions}

This research makes at least three contributions. First, it identifies the different structures that are used to develop the same generic open source product. Prior research has focused on the characteristics of the open source software being developed and not on the structures used to develop it.

The second contribution of this research is that it identifies the factors that lead to the success of open source projects and uses these factors to make recommendations to individuals and organizations that wish to set up open source projects. Prior research has not identified the factors that lead to the success of open source projects.

The third contribution that this research makes is that it links literature streams from sociology, innovation evolution and software development to generate insights on the structure-performance relationship of open source projects. Prior research has used the competitive strategy perspective to examine open source projects. 


\subsection{Relevance}

The results of this research are relevant to managers of information technology groups in colleges and universities. These managers can use the insights and the propositions to increase the likelihood of selecting the right LCMS for their organizations.

This research is also important to top management teams of companies wishing to set up open source projects. Top management teams can use the variables that assess performance to increase the likelihood of establishing successful open source projects.

Organizational theory researchers can obtain insights on how to apply two different perspectives to examine the structure-performance relationship.

\subsection{Organization}

This thesis is divided into six chapters. Chapter 1 is the introduction. Chapter 2 reviews the literature and describes the two theoretical perspectives used in this research. Chapter 3 describes the research method. Chapter 4 presents the data obtained from examining the 12 open source LCMS projects through the lenses of the communities of practice and systems of innovation perspectives. Chapter 5 provides the insights gained from examining the open source projects in the sample as well as the propositions developed. Chapter 6 provides the conclusions and recommendations, identifies the limitations of this research, and suggests areas for future research. 


\section{LITERATURE REVIEW}

The literature review is organized into four sections. The first section reviews the literature on LCMS. The literature on open source structures is reviewed in the second section. The third section examines the theoretical perspectives that will be used to analyze the structure-performance relationship of open source projects. The lessons learned from the extant literature are described in the fourth section.

\subsection{Learning content management systems}

Hitherto, open source has been the paradigm in the software infrastructure domain (servers) with projects such as Apache. Nevertheless, universities and colleges have recently begun to produce open source software in the form of learning content management systems (LCMS) that compete directly with proprietary counterparts (Coppola and Neely, 2004). These systems have emerged as a platform of choice for institutions seeking fast deployment of e-learning.

LCMS is described as a system that is used to create, store, assemble and deliver personalized e-learning content in the form of learning objects (Brennan, Funke and Anderson, 2001). Learning content management systems often strive to achieve a separation of content from presentation, the first being tagged in XML. This allows LCMS to publish to a wide range of formats, platforms, or devices such as print, web, and even wireless information devices (WID) such as Palm handhelds, all from the same source material. 
Although different LCMS offer unique features and functions, the fundamental components are (Donnello, 2002):

- An authoring tool which allows non-programmers to author e-learning content by creating new or reusing existing learning objects

- A dynamic delivery interface that serves up content based on learner profiles, pretests and user queries

- An administrative application to manage student records, launch courses, track student progress. The administration application may also interface with separate learning management systems

- A learning object repository or central database for storing and managing learning content that may be delivered through a variety of media (web, CD-ROM, printed materials) either as individual objects or as part of a larger course structure. Content and programming logic are separated through XML

These suites are particularly effective at providing information (resources, documents, images etc), opportunities to discuss that information (e.g. one click creation of forums and chat spaces), and cooperate in providing information (student uploaded resources, and wiki-style cooperatively produced archives).

The goal behind LCMS is to provide a collaborative authoring environment for creating, and maintaining learning content (Ismail, 2002) in order to have content that can be customized (localized) and assembled in a particular way. Thus, the content becomes 
available as learning objects, packed in a convenient standard way (common packaging scheme). A learning object can contain any type of informational content that can be delivered over the web; this content can be updated, shared, re-used or assembled.

The components of a LCMS are depicted in Figure 1.

Figure 1. Components of a LCMS

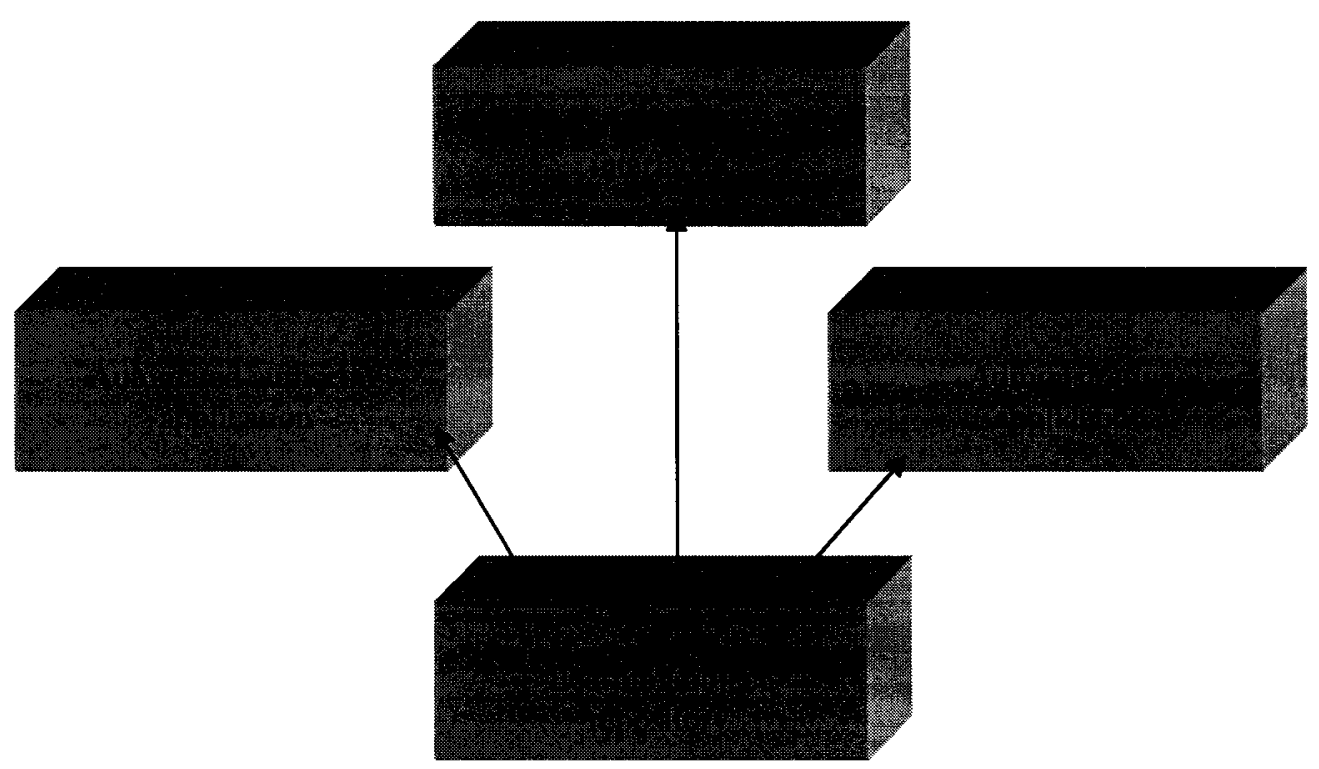

(Source: IDC, 2001)

To find, import, share, reuse, and export learning content in a standardized way, a suite called SCORM that enable web-based learning systems has been developed. This suite is needed to define and access information about learning objects so they can be easily shared among different learning content management systems. 


\subsection{Open source structures}

Open source groups are communities of practice embodied in product development (Lee and Cole, 2003). This concept refers to software systems in which contributors relinquish control of the knowledge they develop (von Hippel and von Krogh, 2003) and whose source code is fully accessible to anyone (Nakakoji, Yamamoto, Nishinaka, Kishida, and Yunwen, 2002). Open source software clearly opposes proprietary software developments which are usually considered expensive in terms of installation and support contracts.

The story of proprietary and open source software can be explained by the metaphor of the "reverent cathedral building" as compared with "the great babbling bazaar of different agendas and approaches" (Raymond, 1999). There are some premises, all credited to Eric Raymond - the author of The Cathedral and the Bazaar -, that describe the core ideas behind the Open Source model: "Release early, Release Often", and "Deal with your users as hackers". In the Cathedral model - proprietary software - bugs in the development process are deep issues that will concern even the most optimistic developer: bugs are hard to find, but harder to fix. In the Open Source world, bugs are small rocks in the trail that "turn pretty shallow when exposed to a thousand of eager co-developers" (Raymond, 1999). Anyone of the users will fix the bug, but the entire community will benefit.

Authors such as Krishnamurthy (2002) have criticized the fact that most OSS programs are actually developed by individuals, rather than by the community acting together. To 
support this argument, Krishnamurthy (2002) referred that in an analysis of 100 open source projects, the median number of developers was 4 and the mode was 1 . Thus, the activities of the gross of the open source community would be restricted to tasks other than the product development itself such as answering questions, and suggesting new features. This finding coincides with that of Lee and Cole (2003) who found a two-tier structure (small core and large periphery) in the Linux Development. The core relies on the periphery to generate patches of computer code. Subsequently, the core selects and retains among the variations to produce an official release. To this classification, $\mathrm{Xu}$ and Madey (2004) have added the project leader, or person who guides the vision and direction of the project, and the active users, who suggest new features and exchange other information by posting messages to forums or mailing lists. The Figure 2 portrays the different roles in open source communities. 
Figure 2. Roles in open source structures

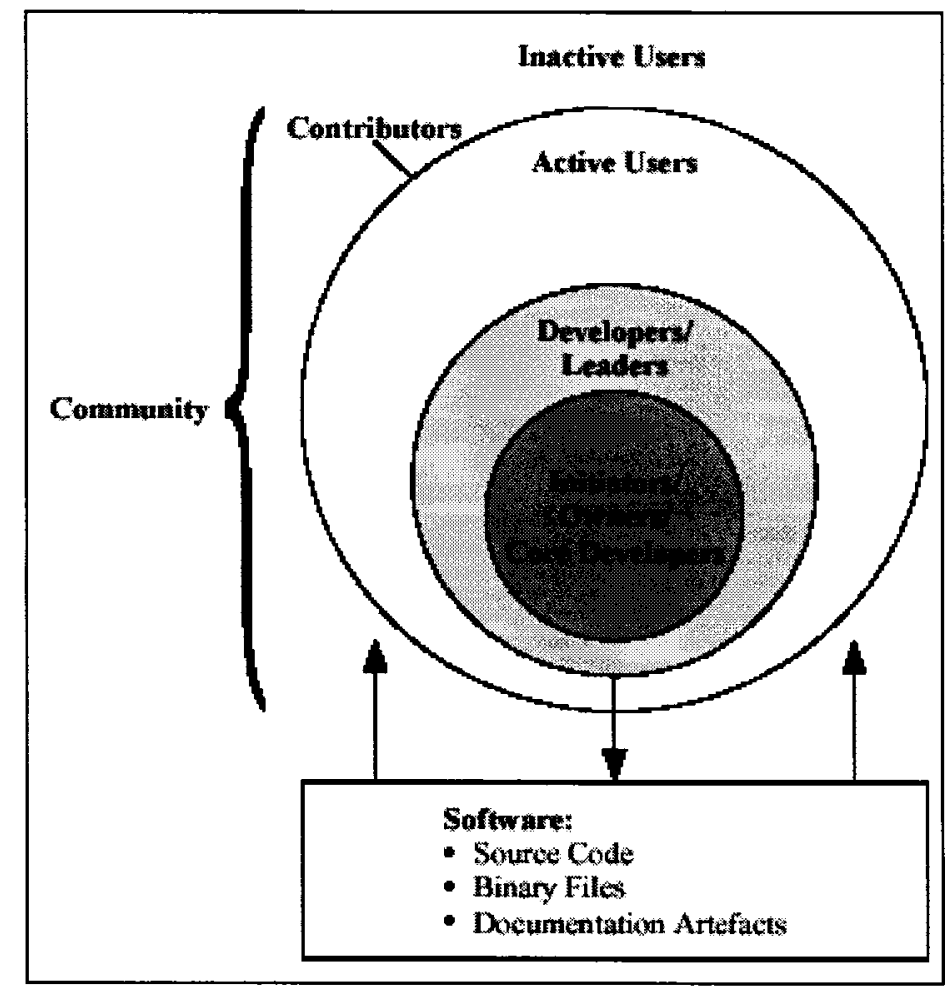

(Source: Open source community building, Sturmer, 2005)

One of the benefits of the open source structure is the possibility of freely use, modify, and redistribute the software without a license fee. However, joining a developer community may not be costless (von Krogh, Spaeth and Lakhani, 2003). Software development usually requires high levels of domain knowledge and experience. Von Krogh et al. (2003) introduced the concept of "contribution barrier" to refer to issues such as the complexity of the source code, the prior domain knowledge and the expertise on the part of the developer; these notions appear particularly related to the specialization of newcomers by distinct modules. Joining a community also brings rewards: newcomers 
share with existing developers greater benefits such as ideas, bug fixing and code (von Krogh et al., 2003).

In their study of innovation at the community level, Lee and Cole (2003) emphasized the fact that problem-solving drives the evolutionary process of knowledge creation and generates structure in a community setting, where this knowledge-creation platform is based on a many to many communication technology. This technology allows for development activity consisting of discussion rooms, mailing list and in general all tools allowing for interactions among developers (Lee and Cole, 2003). A key output of the knowledge creation process is the artefacts. In the particular case of open source software one of the most important artefacts is, of course, the software itself. To account for knowledge-creation mechanisms, Lee and Cole (2003) estimated the size of the development community and the code structure across time (number of modules). The former concept has been perceived in different ways: while for Cavalier (1998) size affects the health and the success of the bazaar, for Krishnamurthy (2002) the concept does not bear importance as most of the open source projects only display a small number of developers. In terms of the speed of development, Lee and Cole (2003) measured how quickly a message was answered and how often new versions were released.

But code is not the only way to contribute to the community work; non-developers may decide to participate in the project only by preparing all aspects related to documentation such as manuals, tutorials, guidelines and end user documentation (Sturmer, 2005). As well, third-party software suppliers may decide to provide complementary products or 
services in the form of interfaces unanticipated by the originator of the open source software (West, 2003).

A summary of the literature on open source communities is presented in Table 1.

Table 1. Structure of an open source community

\begin{tabular}{|l|l|}
\hline \multicolumn{1}{|c|}{ Constructs } & \multicolumn{1}{|c|}{ Research } \\
\hline Size: & Krishnamurthy (2002); Lee and Cole, \\
contribute to the project as opposed to a & (2003); Cavalier (1998) \\
simple head count & \\
\hline Heterogeneity: & \\
Number of types of members: Joiners, & (2003); Xu and Madey (2004) \\
developers and newcomers; core developers, & \\
periphery developers, project leader and & \\
active users & \\
\hline Stability: & \\
The network system allows individuals to & \\
find others with similar interest & \\
\hline Joining: & \\
\hline
\end{tabular}




\begin{tabular}{|l|l|}
\hline - Reasons for joining & \\
\hline Channels of development activity: & Lee and Cole (2003); Von Krogh et al., \\
- Chat rooms & (2003); Sturmer (2005); West (2003) \\
- Mailing lists & \\
- Message threads & \\
- Usability & \\
- Cocumentation & \\
\hline Speed of development: & \\
- Time to get an answer & Lee and Cole (2003); Raymond (1999) \\
- Nelease often, release soon" policy & \\
\hline Barriers and enablers to entry: & \\
\hline - Number of bugs & \\
\hline
\end{tabular}




\subsection{Theoretical perspectives that will guide the generation of insights and} propositions

In this section the two theoretical perspectives that are conducive to insights and propositions on the relationship between structure-performance of LCMS are presented:

- Communities of practice

- Sectoral systems of innovation

\subsubsection{Communities of practice}

The topic of communities of practice is of interest since there is dissatisfaction today with traditional learning methods and arenas (Johnson, 2001). In this vein, communities of practice seem to be a natural model from which to interpret the phenomenon of Learning Content Management Systems (LCMS).

The literature on communities of practice builds primarily on Etienne Wenger's research (Wenger, 1998; Wenger, 2000). A community of practice consists of participants with a bonding to common problems, the pursuit of solutions to those problems (Lave and Wenger, 1991), an eagerness about a topic, the ability to negotiate ${ }^{2}$ goals, the will to improve their practice and the commitment to learning and generating new capabilities (Saint-Onge and Wallace, 2003). Wenger (1998) has found that it is the collective construction of a practice what makes possible to meet the demands of an institution more than its policies, metrics, training, programs and system designs. This practice, in

\footnotetext{
${ }^{2}$ Negotiation is used as explained by Wenger (1998) in the sense of continuous interaction, gradual achievement, agreement and give-and-take.
} 
turn, can be defined in terms of locality, proximity and distance, which are not necessarily congruent with physical distance or even interactions (Wenger, 1998). In the context of communities of practice local and global are different levels of participation that coexist and shape each other in what Wenger (1998) calls the geography of practice.

As a result of interaction, a community of practice has the potential to organize their members so as to produce a collective good, something that no individual member of the community could provide for themselves if they had acted alone (Smith, 2004). Some goods are tangible; others are intangible like goodwill, trust, and identity. In this context, practice is not to be understood as the opposite of theorizing; it is actually a generic concept involving both activities.

The concept of communities of practice has been previously linked to open source communities (Nakakoji et al., 2002). These authors have found that the social mechanism of the community that encourages and enables individual role changes is consistent with the idea of Legitimate Peripheral Participation, a concept emanated from Wenger's work (Wenger, 1998), which emphasizes the difference between newcomers and old-timers and the process of moving from one way of being to the other. The members achieve this shift in state by learning the practice of the open source community, gradually moving from peripheral to full participation (Lave and Wenger, 1991). Furthermore, Nakakoji et al. (2002) sustain that the free access to the code grants new members of an open source community the legitimate access to expertise of mature software development and the opportunity of working together with expert developers. 
Wenger (1998) suggests three dimensions as crucial for the association between practice and community:

- Joint enterprise

- Mutual engagement among members

- Artefacts

Figure 3 illustrates the three dimensions or building blocks of a community of practice from Wenger's perspective (Wenger, 1998). Caution is in place as these dimensions can not be taken separately. The three notions work cooperatively to repair each other's misalignments inherent to the common goal.

Figure 3. Building blocks of a community of practice

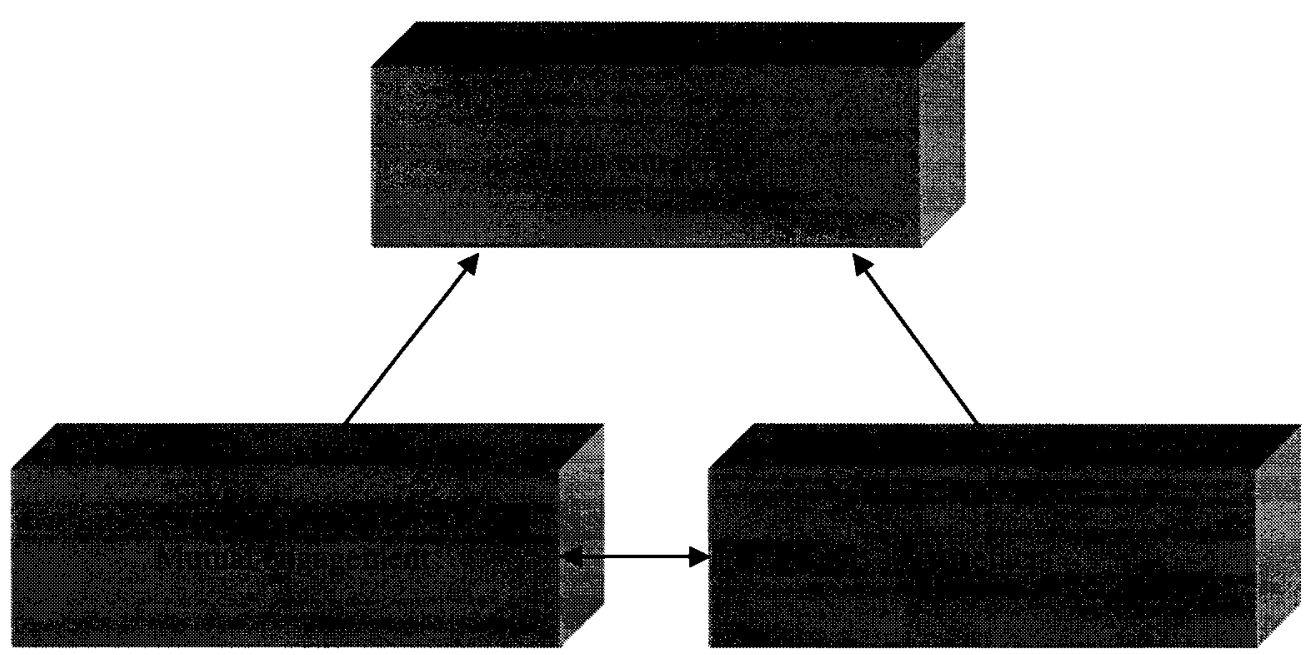

(Source: Communities of practice, Wenger, 1998) 


\subsubsection{Joint enterprise or what the community is about}

Members are bound together in virtue of their joint enterprise which indicates what the community is about (Wenger, 2000).

There exists a governance structure, a core mission (Wenger, 2000), conventions, a shared leadership of members and some form of facilitation. Within communities of practice, the role of the manager changes to that of facilitator. It is the responsibility of the facilitator to ease the learning process: this member acts as a "subtle guide" who eases peer interaction and members-to-newcomers interaction towards "artefacts" (Wenger, 1999).

In the context of communities of practice, the idea of knowledge being transmitted via an expert is replaced by that of knowledge being constructed collectively (Stringer, 1997). Communities of practices generate knowledge that supports the practice through productive inquiry ${ }^{3}$, access to internal information and contributions of members; in this way new knowledge that forms the content or domain of their practice is created by the community and shared by answering to this "productive inquiry" (Saint-Onge and Wallace, 2003). Competence is defined as the ability to contribute to the domain or joint enterprise by replying to other member's inquiries.

\footnotetext{
${ }^{3}$ This "productive inquiry" is the catalyst to understand how communities of practice work (Saint-Onge and Wallace, 2003). New knowledge is created during the process of finding an answer to the productive inquiry whereas tacit knowledge is exchanged to do so.
} 


\subsubsection{Mutual engagement or how the community functions}

This dimension relates to trust, the depth of social capital ${ }^{4}$ and the regular interaction among members. It is crucial if there is no face-to-face contact as in the case of communities built around electronic networks (Howard, 2002). In this case technology is likely to play a significant role as vehicle for creating communities not collocated geographically (Saint-Onge and Wallace, 2003), supporting fellow members or submitting knowledge artefacts. Such a diffusion of knowledge may take place in a wide set of venues it being phone conversations, e-mail exchanging, annual gatherings, chat channels, shared repositories, forums or boards; these engagement enablers are an essential component to the practice. In other words, the community members will weave their conversations in a conceptual space that span all sorts of separate resources, of different depth and relevance to the core interests of the communities of practice (Cornejo, 2004). These connections constitute information channels that reduce the amount of time and investment required to gather and process information (Nahapiet and Ghoshal, 1998).

Inter-member relations are not of equality nonetheless: Some people are core members, some others are peripheral associates (Holmes, 1999). Peripheral participants are those who gradually learn the practices that will eventually make them a core member (Wenger, 1998). They have to be granted legitimacy and have to be provided with full participation that gives exposure to actual practice. In other words, "while in theory all participants [in a community] are equal, in fact group values make some forms of [social]

\footnotetext{
${ }^{4}$ Social capital is the sum of the actual and potential resources embedded within, available through, and derived from the network of relationships possessed by an individual or social unit (Nahapiet and Ghoshal, 1998)
} 
capital more valuable than others and hence, lend those with such capital greater status" (Howard, 2002).

Communities of practice share narratives that could be used to transfer either tacit or explicit knowledge. The strength of shared narratives as enablers of the exchanging of information and sharing of knowledge within the community is emphasized by Lave and Wenger (1991) and Wenger (1998). Knowledge can be explicit in terms of language, tools, documents, symbols, but it can also be implicit in terms of tacit conventions or subtle cues. Interestingly, Gabbay, Le May, Jefferson, Webb, Lovelock, Powell, J., and Lathlean, (2003), in their study on communities of practice improving health service, found that they mostly rely on tacit, experiential knowledge to interpret new knowledge and respond to the productive inquiry. In an exercise intended to help the communities of practice gather knowledge from outside sources, Gabbay et al. (2003) found that mainly people or organizations with relevant information were included; only one suggestion included looking at published literature, which eventually failed to be considered for a follow up.

\subsubsection{Artefacts or what the community produces}

A community of practice grows up around a body of common knowledge shared amongst participants; this common knowledge, Wenger has found (Wenger, 2000), can come in different manners. Over time, the joint pursuit of an enterprise results in a shared repertoire of artefacts (Wenger, 1998). An artefact is a projection of participants onto the world; it is the form given to the participant's understanding. Language, routines, tools, 
styles, ways to do things, events, websites - in short, practices - are assets with the ability to reflect what is developed by the community of practice. These knowledge objects (artefacts) form the knowledge repository that can be referenced to respond to collective queries.

To act as boundary objects (objects that serve to coordinate the perspectives of various communities of practices for a particular purpose), an artefact should have the following features (Wenger, 1998):

- Modularity: Each perspective can attend to one specific portion of the boundary object

- Standardization: The information contained in a boundary object is in a pre-specified form so that each community of practice knows how to deal with it locally

The Table 2 summarizes the concept of organizational structure as suggested by the literature on communities of practice.

Table 2. Structure from the perspective of community of practice

\begin{tabular}{|l|l|l|}
\hline \multicolumn{1}{|c|}{ Dimensions } & \multicolumn{1}{|c|}{ Constructs } & \multicolumn{1}{c|}{ Research } \\
\hline \multirow{2}{*}{ Joint enterprise or } & Core mission & Wenger (2000) \\
\cline { 2 - 3 } community structure & Governance structure & Wenger (1999) \\
\cline { 2 - 3 } & The geography of practice & Wenger (1998) \\
\hline
\end{tabular}




\begin{tabular}{|c|c|c|}
\hline & Density of the social network & Saint-Onge and Wallace (2003) \\
\hline \multirow[t]{4}{*}{$\begin{array}{l}\text { Mutual engagement } \\
\text { among members }\end{array}$} & Engagement enablers & $\begin{array}{l}\text { Saint-Onge and Wallace } \\
\text { (2003); Cornejo (2004); } \\
\text { Nahapiet and Ghoshal (1998) }\end{array}$ \\
\hline & Diversity of roles & $\begin{array}{l}\text { Cornejo (2004); Howard } \\
\text { (2002); Holmes (1999); } \\
\text { Wenger (1998) }\end{array}$ \\
\hline & $\begin{array}{l}\text { Enablers and barriers to enter } \\
\text { (boundary permeability) }\end{array}$ & $\begin{array}{l}\text { Wenger (1998); Gabbay et al. } \\
(2003)\end{array}$ \\
\hline & $\begin{array}{l}\text { Shared knowledge: tacit or } \\
\text { explicit }\end{array}$ & $\begin{array}{l}\text { Gabbay et al. (2003); Wenger } \\
\text { and Lave (1991); Wenger } \\
\text { (1998) }\end{array}$ \\
\hline \multirow[t]{3}{*}{ Artefacts } & Tools for knowledge sharing & Wenger (2000) \\
\hline & Modularity of the artifacts & Wenger (1998) \\
\hline & Standards & Wenger (1998) \\
\hline
\end{tabular}

\subsubsection{Sectoral systems of innovation}

The concept of systems provides a key level of analysis in the examination of innovative and productive activities (Malerba, 2002). A system is an entity composed by components, relationships among the components and attributes towards a common goal (Carlsson, Jacobsson, Holmen, and Rickne, 2002). 
The systems of innovation approach is not a theory in the conventional sense since it does not offer compelling propositions with established and stable relations between variables. It is rather a conceptual perspective that has been influenced by different theories of innovation including learning and evolutionary theories (Edquist and Johnson, 1997). This representation bears a resemblance to that of communities of innovation as explained by Lynn, Reddy and Aram (1996). In their study on organizational ecology, these authors developed a framework to study a phenomenon wider than that of firms and its relationships as a structured system. They proposed the term community of innovation or innovation community to highlight the institutions and organizations directly dealing with the commercialization of a technology; thus, a community of innovation is a set of interacting populations embedded in a dense web of social and economic relationships.

The literature on systems of innovation has referred several possible types of systems and the choice depends on the level of analysis: local (Saxenian, 1994), regional (Braczyk, Cooke and Heidenreich, 1998; Ohmae, 1995), national (Lundvall, 1992; Nelson, 1993; Edquist and Johnson, 1997), sectoral (Breschi and Malerba, 1997; Malerba, 2002), and technological (Carlsson et al., 2002), among others. The common characteristics to all systems of innovation approaches are:

- Innovation and learning are at the centre: the creation and accessibility of knowledge are important 
- It is not possible to define an optimal system of innovation as processes of learning constantly change. Carlsson et al. (2002), along with Eliasson and Eliasson (1996), favour a modern economy approach with extremely rapid sectoral, organizational and institutional change, all embedded within patterns of social change; this combination makes optimization impossible

- Emphasis is put in the interdependence of agents: innovation does not occur in isolation

- Institutions such as regulation agencies and universities are important for innovation processes

A sectoral system, in particular, is defined as a collective emergent outcome of the interaction and co-evolution of its various elements (Malerba, 2002). The concept has also been defined by Breschi and Malerba (1997) as

a system of firms active in developing and making a sector's products and in generating and utilizing a sector's technologies through processes of interaction and cooperation in artefact-technology development and through processes of competition and selection in innovative and market activities

The notion of sectoral systems of innovation originated as a knowledge-based approach. That being said, it becomes clear that the researcher within this arena is concerned with problem - solving activities and with the generation of new knowledge. 
Sectoral systems may prove a useful tool in several aspects: it provides a better understanding of the structure of a sector, its agents and their interaction, and the learning and innovation processes. It is also useful as a descriptive analysis of sectors (Malerba, 2002) and complementary technologies (Carlsson et al., 2002). In a discussion on sectoral systems of innovation, Malerba (2002) noted that one of the areas with less advancement concerns the extent and features of within-sector firm structure and change in the relationships among agents.

There are three dimensions essential to a sectoral system. The first is the cognitive, in virtue of which emphasis is paid to the role of knowledge and learning processes resulting in a new set of sectoral possibilities. This means, in other words, that sectoral systems of innovation have a knowledge base, technologies, inputs and demand (Malerba, 2002). Complementarities are also important in the context of sectoral systems of innovation because they define the boundaries of a system. The second dimension is the economic, consisting of the set of agents who convert sectoral into business opportunities. The agents are individuals at various levels of aggregation, with specific learning processes, competencies, organizational structure, and objectives (Malerba and Orsenigo, 2000). Authors such as Geels (2004) extend the view on sectoral systems of innovation by emphasizing the importance of users and non-organizations in the innovation process. The last dimension is the organizational or institutional that captures the wide range of interactions among the agents engaged in the creation of these technologies. Innovation, in this view, is a collective process where learning is a key determinant (Edquist and Johnson, 1997). 
Taken together, the constructs that define structure for the sectoral systems of innovation perspective are contained in Table 3.

Table 3. Structure from the perspective of sectoral systems of innovation

\begin{tabular}{|c|c|c|}
\hline Dimensions & Constructs & Research \\
\hline \multirow[t]{6}{*}{ Cognitive (attributes) } & Addition of new capabilities & $\begin{array}{l}\text { Carlsson et al. (2002); Carlsson } \\
\text { and Stankiewicz (1991) }\end{array}$ \\
\hline & User competence & Carlsson et al. (2002) \\
\hline & $\begin{array}{l}\text { Accumulation of know-how } \\
\text { and accessibility of knowledge }\end{array}$ & Edquist and Johnson (1997) \\
\hline & $\begin{array}{l}\text { Technological } \\
\text { complementarities }\end{array}$ & Malerba (2002) \\
\hline & Physical artifacts & Malerba (2002) \\
\hline & Development phase & Carlsson et al. (2002) \\
\hline \multirow{8}{*}{$\begin{array}{l}\text { Economic } \\
\text { (components) }\end{array}$} & Public policy agents & \multirow{8}{*}{$\begin{array}{l}\text { Malerba (2002) } \\
\text { Geels (2004) } \\
\text { Malerba and Orsenigo (2000) }\end{array}$} \\
\hline & Organizations & \\
\hline & Partners (Firms) & \\
\hline & Partners (Universities) & \\
\hline & Partners (Research institutes) & \\
\hline & Users & \\
\hline & Developers & \\
\hline & Banks (Funding) & \\
\hline Organizational & Buyer-supplier relationship & Carlsson et al. (2002) \\
\hline
\end{tabular}




\begin{tabular}{|l|l|l|}
\hline (interaction of agents) & Feedback & Carlsson et al. (2002) \\
\cline { 2 - 3 } & Collaborative process & Malerba (2002); Edquist and \\
& & Johnson (1997) \\
\cline { 2 - 3 } & Technology transfer processes & Carlsson et al. (2002) \\
\hline
\end{tabular}

\subsection{Lessons learned}

This section provides the lessons that were learned from examining the literature.

\section{Open source projects are not part of the product development literature}

The frequently quoted reviews of the product development literature (Brown and Eisenhardt, 1995; Krishnan and Ulrich, 2001; Shane and Ulrich, 2004) do not mention open source projects. As a consequence, little is known about how to manage open source projects (Crowston and Howison, 2004) and about the relationship between structure and performance of open source projects.

\section{Successful communities of practice share knowledge outside of organizational boundaries}

In the process of sharing knowledge with outsiders, members of successful communities exchange alternative viewpoints. These influences from outside are seen as valuable in ensuring that the community is exposed to a broad range of thinking (Lesser and Storck, 2001). 
Performance measures in the product development literature might not be applicable to the open source case

Traditional measures of development performance include profit, revenue and market share (Brown and Eisenhardt, 1995). In the open source literature, number of releases, number of users / downloads (Larson and Gobeli, 1989), and number of developers (Crowston and Howison, 2005) are used as performance measures.

Collective action of diverse agents is required to overturn an existing standard Bonaccorsi and Rossi (2003) highlight the importance of heterogeneity in diffusion processes. For example, to overturn existing standards, agent heterogeneity is required.

Continuous interaction between members of an organization increases capability to respond to problems faced by newcomers

A healthy community will facilitate the flow of information and will take care of new comers (von Krogh et al., 2003). 


\section{RESEARCH METHOD}

\subsection{Unit of analysis}

The unit of analysis is an open source project that develops a learning content management system.

\subsection{Study period}

The study period is from May 2003 to May 2005.

\subsection{Research method}

Constructs drawn from communities of practice and sectoral systems of innovation are used to examine the structure-performance relationship of the projects that develop open source learning content management systems.

Table 4 outlines the steps of the research method undertaken. For each step, the last column of Table 4 identifies the dominant activity completed. 
Table 4. Research method

\begin{tabular}{|c|c|c|}
\hline No. & Step & Activity \\
\hline 1 & $\begin{array}{l}\text { Determining research } \\
\text { objective and outcomes }\end{array}$ & $\begin{array}{l}\text { Modeling the objectives and outcomes of this } \\
\text { research. }\end{array}$ \\
\hline 2 & $\begin{array}{l}\text { Selecting theoretical } \\
\text { perspectives }\end{array}$ & $\begin{array}{l}\text { This step provides the rationale for using of } \\
\text { the two theoretical perspectives selected. }\end{array}$ \\
\hline 3 & $\begin{array}{l}\text { Selecting constructs from } \\
\text { theoretical perspectives }\end{array}$ & $\begin{array}{l}\text { A priori specification of constructs from the } \\
\text { two theoretical perspectives is given. }\end{array}$ \\
\hline 4 & Selecting cases & $\begin{array}{l}\text { Definition of the population from which the } \\
\text { overall sample is drawn. } \\
\text { Specification of the set of } 12 \text { LCMS projects } \\
\text { to be examined. } \\
\text { Overall, the sample will be selected on the } \\
\text { basis of the criteria established in the section } \\
3.3 .4\end{array}$ \\
\hline 5 & $\begin{array}{l}\text { Determining performance } \\
\text { measures }\end{array}$ & $\begin{array}{l}\text { Performance measures adequate for the open } \\
\text { source environment are selected. }\end{array}$ \\
\hline 6 & Operationalizing the & Constructs from the Communities of practice \\
\hline
\end{tabular}




\begin{tabular}{|c|c|c|}
\hline & constructs & $\begin{array}{l}\text { perspective need to be operationalized as this } \\
\text { perspective comes from sociology }\end{array}$ \\
\hline 7 & $\begin{array}{l}\text { Collecting data on first } \\
\text { wave of LCMS projects }\end{array}$ & $\begin{array}{l}\text { A coding scheme is developed to replicate the } \\
\text { data collection process across structures. } \\
\text { Data collection protocol is identified. } \\
\text { Collection of information publicly available } \\
\text { on the first eight LCMS projects takes place. }\end{array}$ \\
\hline 8 & $\begin{array}{l}\text { Analyzing data on LCMS } \\
\text { projects }\end{array}$ & $\begin{array}{l}\text { Data on LCMS projects are analyzed through } \\
\text { a process of within-case and cross-case } \\
\text { comparison. }\end{array}$ \\
\hline
\end{tabular}

\subsubsection{Research model}

Figure 4 emphasizes the fact that two perspectives are used to examine the structureperformance relationship of open source projects. 


\section{Figure 4. Research model}

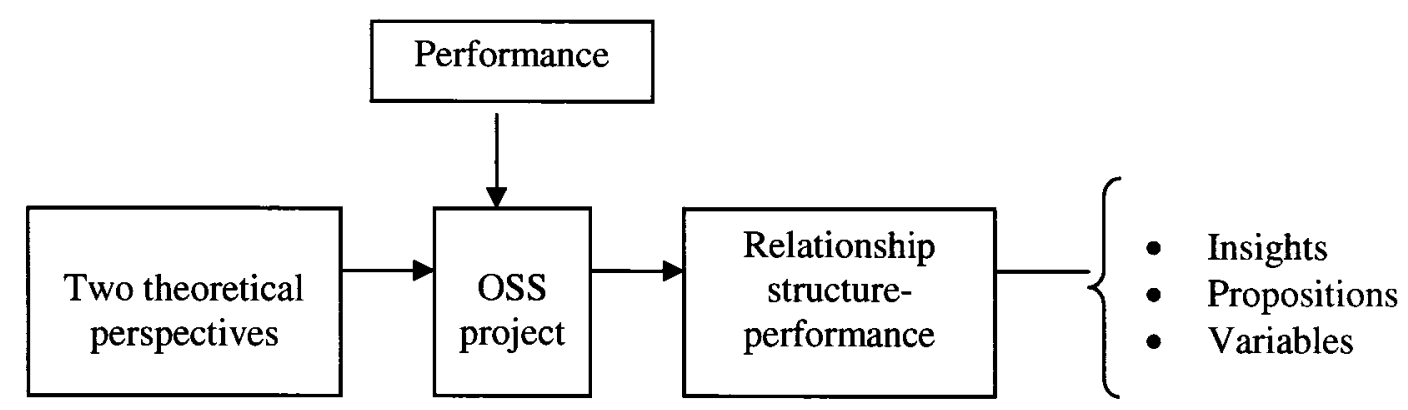

\subsubsection{Rationale for using the two theoretical perspectives}

The theoretical perspectives used in this research are:

- Communities of practice (Wenger, 1998; Wenger, 1999)

- Sectoral systems of innovation (Carlsson et al., 2002; Liu and White, 2001; Geels, 2004)

The community of practice perspective was selected to examine open source projects because it highlights the importance of knowledge as a critical asset that needs to be managed strategically. The importance of the community of practice perspective in companies such as IBM (Gongla and Rizzuto, 2004), Clarica (Saint-Onge and Wallace, 2003), and Xerox (Storck and Hill, 2000) has been documented elsewhere.

Open source projects seem to be a good fit with the concept of communities of practice. According to Wenger (2000), the successes of these communities depend on their ability to design themselves as learning systems. An open source project can be conceptualized 
as a community of practice that strives to produce software, improve productivity and provide members with the proper setting to learn about the open source software being developed.

The sectoral system of innovation perspective was selected to examine open source projects because it highlights the roles of non-firm organizations in the innovation process.

\subsubsection{Constructs selected from theoretical perspectives}

For the purpose of this research, the following constructs were selected from the communities of practice perspective: (i) core mission, (ii) governance structure, (iii) the geography of practice, (iv) density of the social network, (v) diversity of roles, and (vi) compliance with standards.

The following constructs from the sectoral systems of innovation perspective were selected: (i) buyer-supplier relationship, (ii) partners, (iii), technological complementarities, and (iv) collaborative process.

\subsubsection{Sample selection}

The sample used in this research was drawn from the population of open source projects that develop LCMS for use at universities and colleges. 
The criteria to select the sample were:

- The open source project is identified in http://edutech.ch/lms/ev3/

- The open source project has its own web site

- The open source software developed by the project is used in at least three educational institutions

\subsubsection{Performance measures}

Project performance can be defined in several ways. The use of a variety of performance measures provides a better understanding of the project (Crowston and Howison, 2005).

In this research, three measures of the performance of open source projects were used: number of releases, number of users / downloads, and number of developers that contribute to the open source project.

Number of releases of stable versions of the source code is used as a proxy for project growth.

Number of users and number of downloads are used as a proxy for the size of the network of interested users (Bonaccorsi and Rossi, 2003; Larson and Gobeli, 1989).

Number of developers is used as proxy for size of the structure that develops the open source software. Ability to attract a large number of developers to an open source project is important for success (Crowston and Howison, 2005). A small number of developers 
might pose a threat to the sustainability of the open source project (Crowston and Howison, 2004)

\subsubsection{Operationalizing the constructs}

Table 5 associates the constructs of the two perspectives with the data used to measure them.

Table 5. Data used to operationalize constructs

\begin{tabular}{|l|l|l|}
\hline \multicolumn{1}{|c|}{ Constructs } & \multicolumn{1}{|c|}{ Variable } & \multicolumn{1}{c|}{ Data } \\
\hline Core mission & Core mission & $\bullet$ General or niche \\
\hline Governance & Governance & $\bullet$ Project board \\
& & $\bullet$ Community leader \\
\hline Geography of practice & Location of the core team & $\bullet$ Distributed \\
\hline Density of the social & Number of bugs reported & $\bullet$ Number of bugs \\
\hline network & & \\
\hline Diversity of roles & Diversity of roles & $\bullet$ High diversity of roles \\
& & $\bullet$ Low diversity of roles \\
\hline
\end{tabular}




\begin{tabular}{|c|c|c|}
\hline Compliance with standards & Compliance with standards & $\begin{array}{l}\text { - Compliance with SCORM } \\
\text { - Compliance with IMS- } \\
\text { QTI } \\
\text { - Compliance with IMS-CP }\end{array}$ \\
\hline $\begin{array}{l}\text { Technological } \\
\text { complementarities }\end{array}$ & $\begin{array}{l}\text { Complementary products } \\
\text { and services }\end{array}$ & $\begin{array}{l}\text { - Complementary products } \\
\text { - Complementary services }\end{array}$ \\
\hline Partners & Partners & $\begin{array}{l}\text { - Research institutions } \\
\text { - Firms } \\
\text { - Universities }\end{array}$ \\
\hline Buyer-supplier relationship & User-developer proximity & $\begin{array}{l}\text { Users reply to requests } \\
\text { from users } \\
\text { - Developers reply to } \\
\text { requests from users } \\
\text { - Leader replies to } \\
\text { requests from users }\end{array}$ \\
\hline Collaborative process & $\begin{array}{l}\text { Communication channels } \\
\text { among developers }\end{array}$ & $\begin{array}{l}\text { Number of developer } \\
\text { discussion forums }\end{array}$ \\
\hline
\end{tabular}

\subsubsection{Data collection}

For each open source project, the data were collected from the project's website.

Particularly useful are the archival records from the project web site (online discussion 
archives, forums, improvement proposals, FAQ and $\mathrm{CVS}^{5}$ ), publicly available documents related to the LCMS system, and personal communications with the project's main developers.

For each variable identified in Table 5, Table 6 shows the source used to collect the data.

${ }^{5} \mathrm{CVS}$ : A concurrent versioning system is a widely used open source code control system. Anyone can read from a CVS, but only members with guaranteed access can write to it. 
Table 6. Source of data

\begin{tabular}{|l|l|}
\hline \multicolumn{1}{|c|}{ Variable } & \multicolumn{1}{|c|}{ Data source } \\
\hline Core mission & $\begin{array}{l}\text { Project's web site (introductory } \\
\text { page; IRC chat rooms) }\end{array}$ \\
\hline Governance structure & $\begin{array}{l}\text { Project's web site (introductory } \\
\text { page) / sourceforge.net }\end{array}$ \\
\hline Location of the core team & Project's web site (About) \\
\hline Number of bugs reported & Project's web site (bug tracker \\
system)
\end{tabular}




\begin{tabular}{|l|l|}
\hline Frequency of releases & $\begin{array}{l}\text { Project's web site (download } \\
\text { page or release note page) / } \\
\text { sourceforge.net }\end{array}$ \\
\hline Number of users (downloads) & Project's web site (Sites) / \\
sourceforge.net
\end{tabular}

\subsubsection{Data analyzes}

The data were examined using the following steps:

Step 1: Important communications among developers or among developers and users were marked to preserve the explanatory ability of the insights and propositions.

Step 2: Prepared write-ups of the open source projects included in the sample. The purpose of this step, as Eisenhardt (1989) affirms, is to become intimately familiar with each case.

Step 3: Divergent techniques were used to compare open source projects (Eisenhardt, 1989). First, the variables used as proxies for the constructs of the theoretical perspectives were used to compare open source projects. Second, open source projects were categorized as high and low performers based on number of releases, number of downloads, and number of developers. Third, we organized the open source projects into concentrated and distributed categories. 
Step 4: Once a pair structural issue - performance is identified, it is compared with the extant literature, first only considering the two theoretical perspectives and then a broader literature. 


\section{SAMPLE AND DATA}

This chapter is organized into four sections. The first section identifies the sample used in this research. The second section provides write-ups for the open source projects included in the sample. The third section provides the data used in this research. The final section identifies the insights gained from examining each open source project organized in terms of the constructs identified from the two perspectives.

\subsection{Sample}

Table 7 identifies the 12 open source projects in the sample organized by the wave used to collect and analyze data. The first and second waves were comprised of 8 and 4 open source projects respectively. Table 7 also provides the addresses of the projects' websites.

Table 7. Open source projects in the sample

\begin{tabular}{|c|c|}
\hline Project name & Project's website \\
\hline \multicolumn{2}{|l|}{ FIRST WAVE $(\mathrm{N}=8)$} \\
\hline $\operatorname{dotLRN}$ & www.dotlrn.org \\
\hline Moodle & www.moodle.org \\
\hline Ilias & www.ilias.de \\
\hline ATutor & www.atutor.ca \\
\hline Claroline & www.claroline.net \\
\hline Olat & www.olat.org \\
\hline
\end{tabular}




\begin{tabular}{|l|l|}
\hline Sakai & www.sakaiproject.org \\
\hline Kewl.NextGen & www.elearn.uwc.ac.za \\
\hline SECOND WAVE (N=4) & www.dokeos.com \\
\hline Dokeos & www.bazaar.athabascau.ca \\
\hline Bazaar & www.manhattan.sourceforge.net \\
\hline Manhattan & www.eledge.sourceforge.net \\
\hline Eledge & \\
\hline
\end{tabular}

\subsection{Open source projects that develop LCMS}

\subsection{1 dotLRN}

dotLRN is a fully open source e-learning platform. dotLRN was a software originally designed by OpenForce for MIT Sloan School. Afterwards, MIT decided to open up the code and follow the open source path. In its early stage, dotLRN was marketed as a joint initiative of MIT and the University of Heidelberg.

dotLRN developer forums are combined with those belonging to the OpenACS (Open Architecture Community System), an advanced toolkit used to develop dotLRN. The dotLRN developer forum is not hosted in the project web site; it is actually hosted in the Open ACS web site.

Nowadays dotLRN is backed by a worldwide consortium of educational institutions, nonprofit organizations, industry partners, open source developers and by the dotLRN 
Consortium. Consortium member institutions work together to support each other's deployments and to accelerate and expand the adoption and development of dotLRN. To this end, the Consortium certifies components as dotLRN compliant, coordinates software development plans, and maintains ties with OpenACS.

dotLRN is governed by member institutions, both at the university and industry levels. It also has an advisory committee composed by university members and independent researchers and a self-managed working committee.

dotLRN is in use at over 20 colleges and universities worldwide, including the University of Heidelberg (in Germany) and the University of New Delhi. Several organizations and research groups are also using the platform, including the E-Lane Project in Europe and Latin America.

\subsubsection{Moodle}

Moodle is a software package for LCMS in a social constructionist framework of education. This research project started in 2000 in Australia as part of a $\mathrm{PhD}$ thesis. The software is used all over the world by universities, colleges, companies and independent teachers. In 2003 the company Moodle started offering professional support and management of Moodle installations. 
Moodle partners are a group of professionals who are serious about providing quality services to users of Moodle software, ranging from basic support to the development and implementation of complete IT solutions.

\subsubsection{Ilias}

The project started in 2000 at the University of Cologne, Germany. Ilias is a powerful LCMS that allows users to create, edit, and publish learning and teaching material in an integrated system with their normal web browsers. It is the first LCMS software to reach SCORM conformance.

ILIAS allows efficient creation of courses and course materials. It offers standardized tools and templates for the learning and working process including integrated navigation and administration.

\subsubsection{ATutor}

Initially the software was proprietary, then it migrated to open source (Ahmed, 2005). ATutor originated in Canada in 2002.

ATutor complies with accessibility standards W3C WCAG 1.0, accessibility specifications at the AA+ level, allowing access to all potential learners, instructors, and administrators, including those with disabilities who may be accessing the system using assistive technologies. Conformance with W3C XHTML 1.0 specifications ensures that ATutor is presented consistently in any standards compliant technology. 


\subsubsection{Claroline}

The Claroline project was initiated in 2000 at the Catholic University of Louvain (Belgium) by Thomas De Praetere and was financially supported by the Louvain Foundation. It became available as open source in January 2002.

Claroline is a free application based on PHY/MySQL, distributed under the GPL license. The software is built over sound pedagogical principles allowing a large variety of pedagogical setup including widening of traditional classroom and online collaborative learning.

\subsubsection{Olat}

The Learning Management System OLAT is licensed under the Apache Software License. Developed since 1999 at University of Zürich, this software has support for various Elearning standards such as IMS-CP, IMS-QTI and SCORM.

Olat is $100 \%$ pure java. Official support for OLAT is available at the Multimedia \& eLearning Center for Swiss university members. Commercial support is available through goodsolutions.

\subsubsection{Sakai}

Sakai is a community source describing a model for the purposeful coordinating of work in a community. It is based on many of the principles of open source development efforts, but community source efforts rely more explicitly on defined roles, responsibilities, and 
funded commitments by community members than some open source development models. It was founded by the University of Michigan, Indiana University, MIT, Stanford, the uPortal Consortium, and the Open Knowledge Initiative (OKI) with the support of the Andrew W. Mellon Foundation. Each institution has (and is using) built a custom learning content management system:

\section{Indiana University: OnCourse}

2. Massachusetts Institute of Technology: Stellar

3. Stanford University: CourseWorks

4. University of Michigan: CHEF

The project is producing open source LCMS software with the first release in July 2004. Sakai seeks to address the problem of software adoption by pooling resources, and focusing them on one framework that is flexible enough to accommodate many different tools and environments.

The Sakai Educational Partners Programme (SEPP) is meant to provide a way into Sakai for institutions other than the founders on both the technical and strategic level. Initially, partners will get support from Sakai core developers, a knowledge base, pre-release code, training events, an internal tool market and an opportunity to give input on development directions. The SEPP has its own dedicated staff. After two years, the intention is that the 
SEPP partners gradually take over the reigns and direct development.

\subsubsection{Kewl.NextGen}

Developed at the University of the Western Cape, South Africa, Kewl.NextGen is an advanced learning management system that was developed in ASP and runs on Microsoft servers with MS-SQL server as the database. Although running on the proprietary Microsoft platforms, the code is open source and freely available for download from http://cvs.uwc.ac.za/.

Even though world class software will be produced within this project, this is not a software development project. Rather it is a project about human development, about capacity building, and about creating opportunities for people through the formation of transnational alliances, both within and outside of Africa.

\subsubsection{Dokeos}

The main goals of Dokeos are to be a very user friendly and flexible system with an easy to use interface; users, then, should have minimal notice of the tools and maximum attention for the content. Dokeos is written in PHP and uses MySQL as a database. Dokeos.com is also a Belgian company providing hosting, support, and services around e-learning and the Dokeos platform. The company contributes back to the community by paying some Dokeos developers. 


\subsubsection{Bazaar}

It started life as a plain web board conferencing system but has rapidly evolved into an integrated information system. Bazaar is a LCMS developed at Athabasca University Canada's Open University. It requires an Apache Web-server and a MySQL database, and uses CPAN Perl modules.

\subsubsection{Manhattan}

Manhattan is a free system designed for Linux and released under the GNU General Public License. It is written entirely in the C programming language and is $100 \%$ database-free.

The software includes a variety of discussion groups, live chat, areas for the teacher to post the syllabus and other handouts and notices, a module for organizing online assignments, a grades module, a surveys module, and a unique, web-based email system open only to students in the class. The system was developed at Western New England College.

\subsubsection{Eledge}

Eledge is a course management system developed by Chuck Wright at the University of Utah (Department of Chemistry). It consists of a collection of Java servlets that utilize a MySQL database back end to store information and course content. 


\subsection{Data collected}

Table 8 provides the data for the 12 open source projects. The decision on the categories used for each construct was made at the data collection step.

Table 9, 10 and 11 rank the open source projects based on the three measures of performance used in this study: number of releases, number of users/downloads, and number of developers. 
Table 8. Data collected for open source projects

\begin{tabular}{|c|c|c|c|c|c|c|c|c|c|c|c|c|}
\hline$\overline{\text { Data }}$ & dotLRN & Moodle & Ilias & ATutor & Claroline & Olat & Sakai & $\begin{array}{c}\text { Kewl.Nex } \\
\text { tGen }\end{array}$ & Dokeos & Bazaar & \begin{tabular}{|c|}
$\begin{array}{c}\text { Manhatta } \\
\text { n }\end{array}$ \\
\end{tabular} & $\begin{array}{c}\text { Eledg } \\
\text { e }\end{array}$ \\
\hline $\begin{array}{l}\text { Governance: } \\
\text { Project manager: } \\
\text { M } \\
\text { Project Board: B } \\
\text { Community } \\
\text { leader: CL }\end{array}$ & B & $\mathrm{CL}$ & $\mathbf{M}$ & $\mathbf{M}$ & B & $\mathbf{M}$ & B & M & $\mathbf{M}$ & B & $\mathbf{M}$ & $\mathbf{M}$ \\
\hline $\begin{array}{l}\text { Core mission: } \\
\text { IT generic: IT } \\
\text { Specialized by } \\
\text { user: S } \\
\text { Particular learning } \\
\text { approach: P }\end{array}$ & IT & $P$ & IT & $S$ & $P$ & IT & IT & IT & IT & IT & IT & IT \\
\hline $\begin{array}{l}\text { Number of } \\
\text { discussion forums } \\
\text { for developers to } \\
\text { communicate }\end{array}$ & 1 & 9 & 1 & 1 & 1 & 1 & 1 & 1 & 1 & 1 & 1 & 1 \\
\hline $\begin{array}{l}\text { Number of bugs } \\
\text { reported }\end{array}$ & 765 & 1633 & 366 & 247 & 53 & 101 & 221 & 55 & 145 & 4 & 1 & 21 \\
\hline $\begin{array}{l}\text { Diversity of roles: } \\
\text { High diversity: } \mathrm{H} \\
\text { Low diversity: } \mathrm{F}\end{array}$ & $\mathrm{H}$ & $\mathrm{H}$ & $\mathrm{F}$ & $\mathrm{H}$ & $\mathrm{F}$ & $\mathbf{H}$ & $\mathbf{H}$ & $\mathrm{H}$ & $\mathrm{F}$ & $\mathrm{F}$ & $\mathrm{F}$ & $\mathrm{F}$ \\
\hline $\begin{array}{l}\text { Compliance with } \\
\text { standards: }\end{array}$ & TC & $\overline{P C}$ & $\overline{\mathrm{PC}}$ & TC & PC & PC & TC & $\overline{\mathrm{PC}}$ & NC & $\mathrm{NC}$ & $\mathrm{NC}$ & $\mathrm{NC}$ \\
\hline
\end{tabular}




\begin{tabular}{|c|c|c|c|c|c|c|c|c|c|c|c|c|}
\hline $\begin{array}{l}\text { Total compliance: } \\
\text { TC } \\
\text { No compliance: } \\
\text { NC } \\
\text { Partial } \\
\text { compliance: PC }\end{array}$ & & & & & & & & & & & & \\
\hline $\begin{array}{l}\text { User-developer } \\
\text { proximity: } \\
\text { Structure is } \\
\text { strongly user } \\
\text { oriented: UO } \\
\text { Structure is not } \\
\text { user oriented: } \\
\text { NUO }\end{array}$ & $\overline{\mathrm{UO}}$ & UO & UO & NUO & UO & NUO & NUO & NUO & \begin{tabular}{|l|} 
UO \\
\end{tabular} & NUO & NUO & NUO \\
\hline $\begin{array}{l}\text { Complementary } \\
\text { products and } \\
\text { services: } \\
\text { Products and } \\
\text { Services: CPS } \\
\text { Only services: S } \\
\text { Services, but } \\
\text { offered by } \\
\text { affiliated } \\
\text { company: AS }\end{array}$ & $S$ & $\mathrm{~S}$ & AS & $\mathrm{S}$ & No & AS & AS & $\overline{\mathrm{AS}}$ & $\mathrm{S}$ & No & No & No \\
\hline $\begin{array}{l}\text { Partners: } \\
\text { Three types } \\
\text { (firms, universities } \\
\text { and research } \\
\text { institutions): TP } \\
\text { Two types of } \\
\text { partners: }\end{array}$ & $\mathrm{TP}$ & OP & WP & TP & $\begin{array}{l}\text { No } \\
\text { partners }\end{array}$ & OP & TP & OP & OP & $\begin{array}{l}\text { No } \\
\text { partners }\end{array}$ & $\begin{array}{l}\text { No } \\
\text { partners }\end{array}$ & $\begin{array}{l}\text { No } \\
\text { partne } \\
\text { ss }\end{array}$ \\
\hline
\end{tabular}




\begin{tabular}{|l|l|l|l|l|l|l|l|l|l|l|}
\hline $\begin{array}{l}\text { WP } \\
\text { One type of } \\
\text { partner (OP) }\end{array}$ & & & & & & & & & & \\
\end{tabular}


Table 9. Open source projects ranked by number of releases

\begin{tabular}{|l|c|}
\hline \multicolumn{1}{|c|}{ Open source } & Number of releases \\
\hline Moodle & 5 \\
\hline Ilias & 4 \\
\hline dotLRN & 3 \\
\hline Claroline & 3 \\
\hline Olat & 3 \\
\hline Manhattan & 2 \\
\hline ATutor & 2 \\
\hline Sakai & 2 \\
\hline Kewl.NextGen & 2 \\
\hline Dokeos & 2 \\
\hline Bazaar & \\
\hline Eledge & \\
\hline
\end{tabular}


Table 10. Open source projects ranked by number of users / downloads

\begin{tabular}{|l|c|}
\hline \multicolumn{1}{|c|}{ Open source } & Number of users / downloads \\
\hline Sakai & 84000 users \\
\hline Moodle & 65725 downloads \\
\hline Claroline & 20000 users \\
\hline dotLRN & 17787 users \\
\hline ATutor & 9225 downloads \\
\hline Manhattan & 7000 downloads \\
\hline Ilias & 6000 users \\
\hline Eledge & 4400 downloads \\
\hline Olat & 3100 users \\
\hline Kewl.NextGen & 2563 downloads \\
\hline Bazaar & 1586 downloads \\
\hline Dokeos & 439 downloads \\
\hline
\end{tabular}


Table 11. Open source projects ranked by number of developers

\begin{tabular}{|l|c|}
\hline \multicolumn{1}{|c|}{$\begin{array}{c}\text { Open source } \\
\text { project }\end{array}$} & Number of developers \\
\hline Moodle & 129 \\
\hline Bazaar & 15 \\
\hline ATutor & 12 \\
\hline Kewl.NextGen & 12 \\
\hline Dokeos & 10 \\
\hline Dotlrn & 9 \\
\hline Claroline & 8 \\
\hline Olat & 7 \\
\hline Sakai & 7 \\
\hline Ilias & 5 \\
\hline Eledge & 2 \\
\hline Manhattan & \\
\hline
\end{tabular}

4.4 Using the constructs of two perspectives to examine open source projects individually

Tables 12 to 23 provide the insights gained from using the constructs of the communities of practice and sectoral systems of innovation perspectives to examine the 12 open source projects in the sample. 
Table 12. dotLRN

\begin{tabular}{|c|c|}
\hline $\begin{array}{l}\text { Theoretical } \\
\text { perspective }\end{array}$ & Insights \\
\hline $\begin{array}{l}\text { Communities } \\
\text { of practice }\end{array}$ & 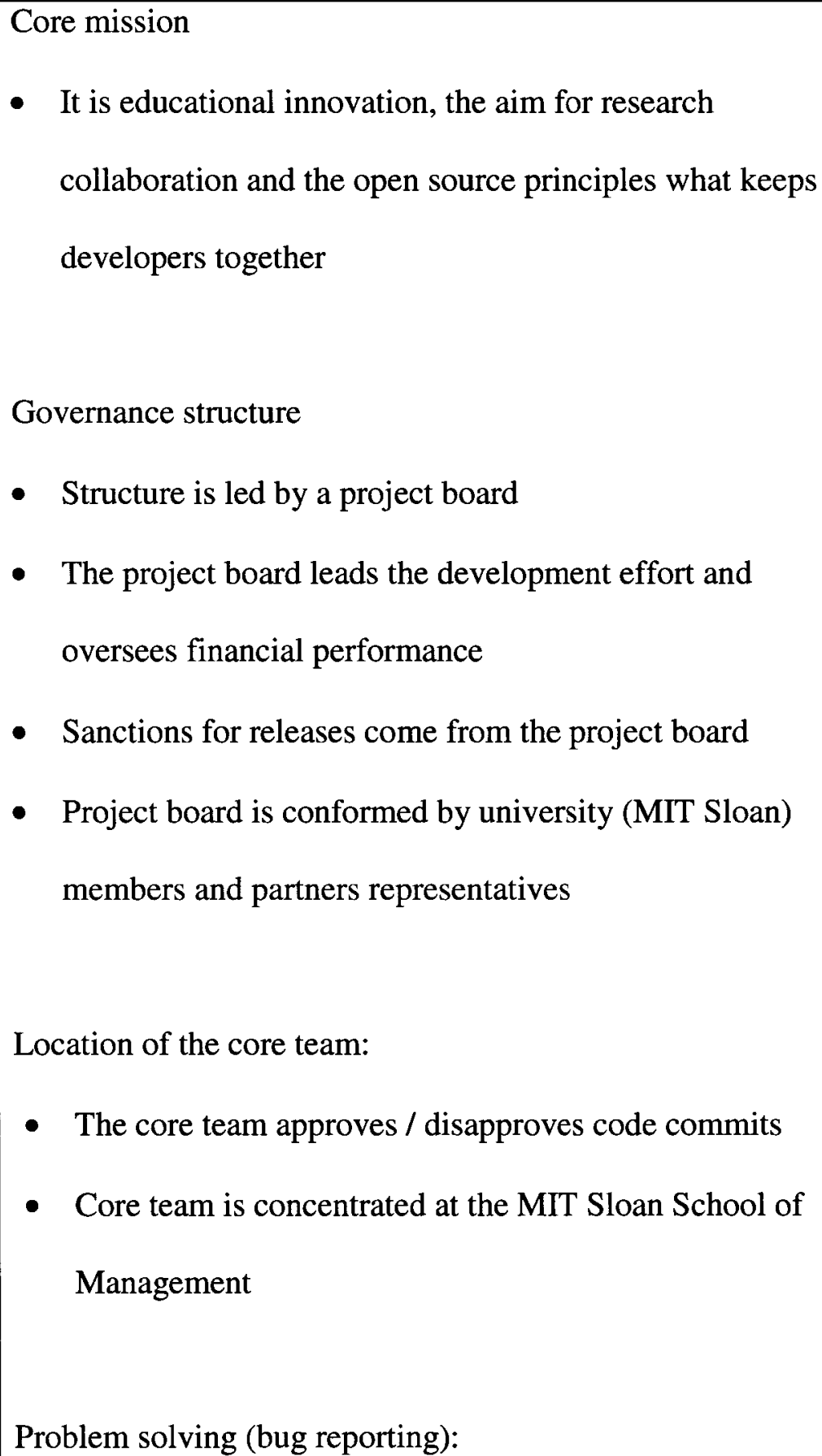 \\
\hline
\end{tabular}




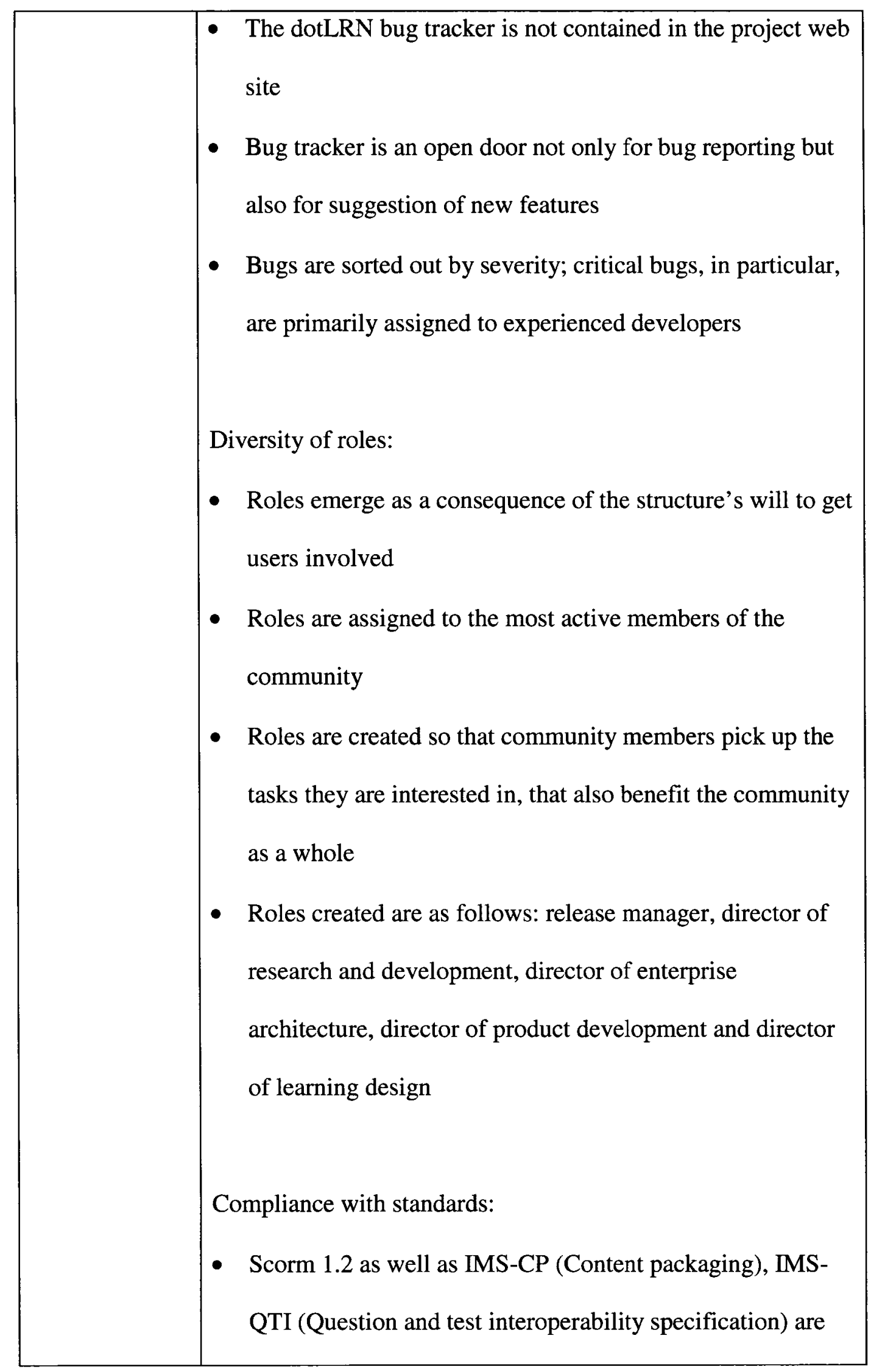




\begin{tabular}{|c|c|}
\hline & $\begin{array}{l}\text { supported } \\
\text { - Standards are supported with interoperability in mind } \\
\text { Occasionally dotLRN developers test its compatibility with } \\
\text { other LCMS } \\
\text { Standards are considered vital as they permit collaboration } \\
\text { among members of the international learning community; } \\
\text { however standards are not satisfactorily implemented yet } \\
\text { Its SCORM compliance is not certified by ADL, the entity } \\
\text { in charge of certifying SCORM compliant products }\end{array}$ \\
\hline $\begin{array}{l}\text { Systems of } \\
\text { innovation }\end{array}$ & $\begin{array}{l}\text { Complementary products and services: } \\
\text { - Products are offered by the Open ACS Consortium or by } \\
\text { companies affiliated to it, but are not offered directly by the } \\
\text { organization developing the LCMS } \\
\text { Partners: } \\
\text { dotLRN partners take part on the development process as } \\
\text { some partners are also users } \\
\text { Partners are universities (such as University of Heidelberg } \\
\text { in German), colleges (such as St. Mary's College of } \\
\text { Maryland, in US), firms (such as Elearning Network of } \\
\text { Australasia) and research institutions (such as E-Lane, the } \\
\text { European-Latin American New Education) }\end{array}$ \\
\hline
\end{tabular}


User-developer proximity:

- Some organizations using dotLRN are also part of the .LRN consortium, which results in more collaboration and a faster development process (users such as University of Heidelberg are also developers)

- MIT Sloan uses dotLRN

- Users have the possibility of providing feedback via the bug tracker system

- There is a section called "improvement proposal" in which community members can suggest tips for the better functioning of the system

Communication channels among developers:

- The dotLRN developer forum is considered as a means to share software expertise

- In general the developer forum serves technical (i.e. information on releases) and non-technical (i.e. documentation) purposes

- The vast majority of interaction occurs over mailing lists. Developers also have the opportunity of face-to-face meetings

- Communication brings visibility to the development 


\begin{tabular}{|l|l|}
\hline process \\
The developer forum in dotLRN is located at the Open \\
ACS Web site, is not located at the dotLRN web site \\
$\begin{array}{l}\text { There is an IRC chat room where all conversations are } \\
\text { registered in a daily log }\end{array}$
\end{tabular}

Table 13. Moodle

\begin{tabular}{|c|c|}
\hline $\begin{array}{l}\text { Theoretical } \\
\text { perspective }\end{array}$ & Insights \\
\hline $\begin{array}{l}\text { Communities } \\
\text { of practice }\end{array}$ & $\begin{array}{l}\text { Core mission: } \\
\text { Moodle is designed using sound pedagogical principles to } \\
\text { communities } \\
\text { - Moodle is also a company helping educational } \\
\text { organizations launch and develop blended learning } \\
\text { programs } \\
\text { Governance structure: } \\
\text { The head of the project is the leader, who is also the } \\
\text { initiator of the project. } \\
\text { The leader ultimately accepts or refuses code commits. }\end{array}$ \\
\hline
\end{tabular}




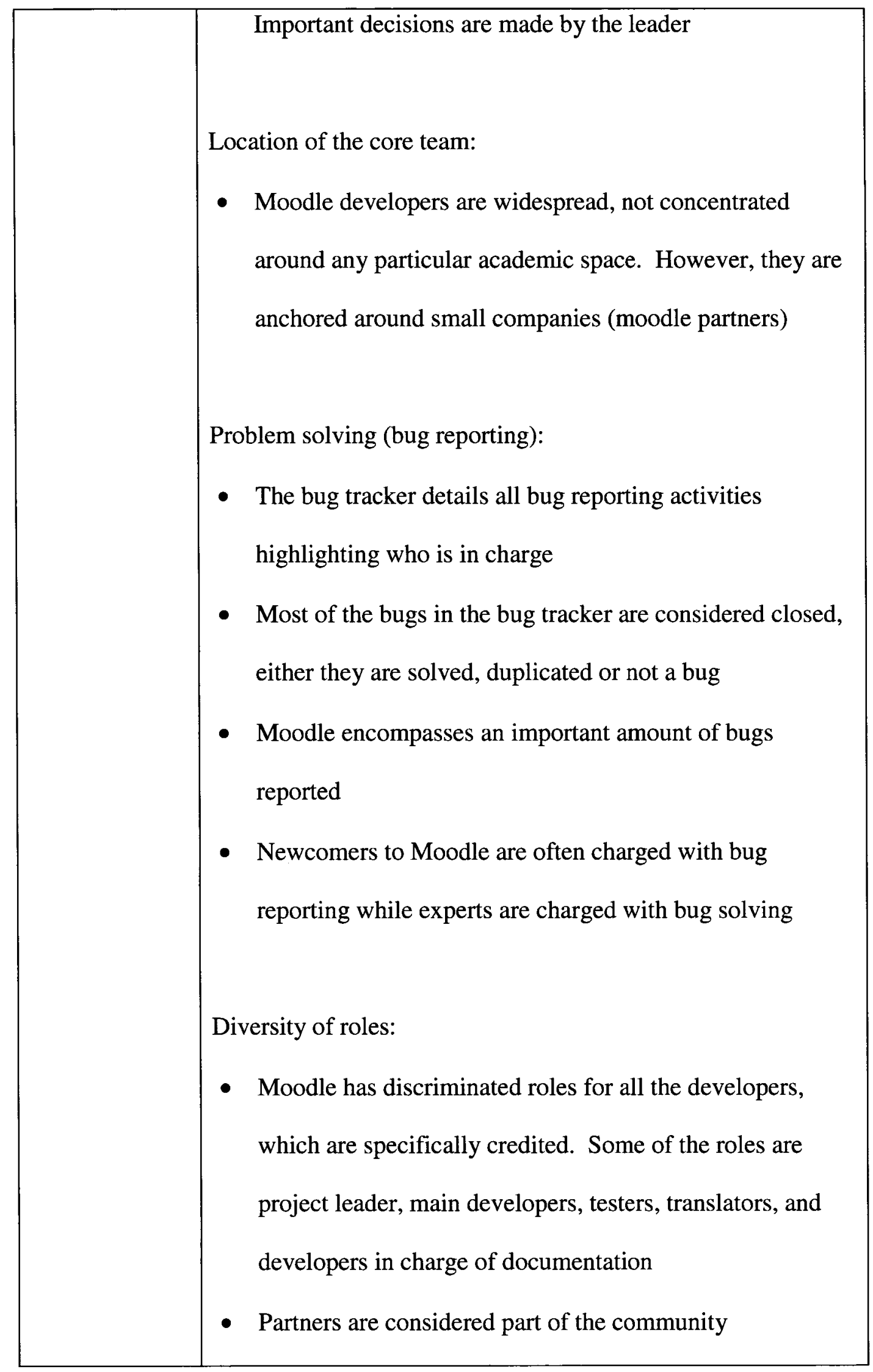




\begin{tabular}{|c|c|}
\hline & $\begin{array}{l}\text { There are facilitators (or moderators) for each one of the } \\
\text { modules: Moodle conferences, Moodle documentation, } \\
\text { Moodle exchange, Moodle for business users, Moodle for } \\
\text { language teaching and Moodle certification } \\
\text { Compliance with standards: } \\
\text { The SCORM module is fully compliant with the SCORM } \\
\text { 1.2 standard. As a result Moodle is able to import quizzes } \\
\text { from WebCT or Blackboard (proprietary LCMS) } \\
\text { Moodle does not comply with IMS-CP or IMS-QTI } \\
\text { Its SCORM compliance is not certified by ADL, the entity } \\
\text { in charge of certifying SCORM compliant products } \\
\text { Sakai and Moodle are working together to achieve } \\
\text { interoperability, along with two proprietary LCMS, } \\
\text { meffort to create a standard by which third-party tools can } \\
\text { interoperate with a variety of learning content } \\
\text { management systems) }\end{array}$ \\
\hline $\begin{array}{l}\text { Systems of } \\
\text { innovation }\end{array}$ & $\begin{array}{l}\text { Complementary products and services: } \\
\text { - Moodle itself offers commercial services via moodle.com }\end{array}$ \\
\hline
\end{tabular}




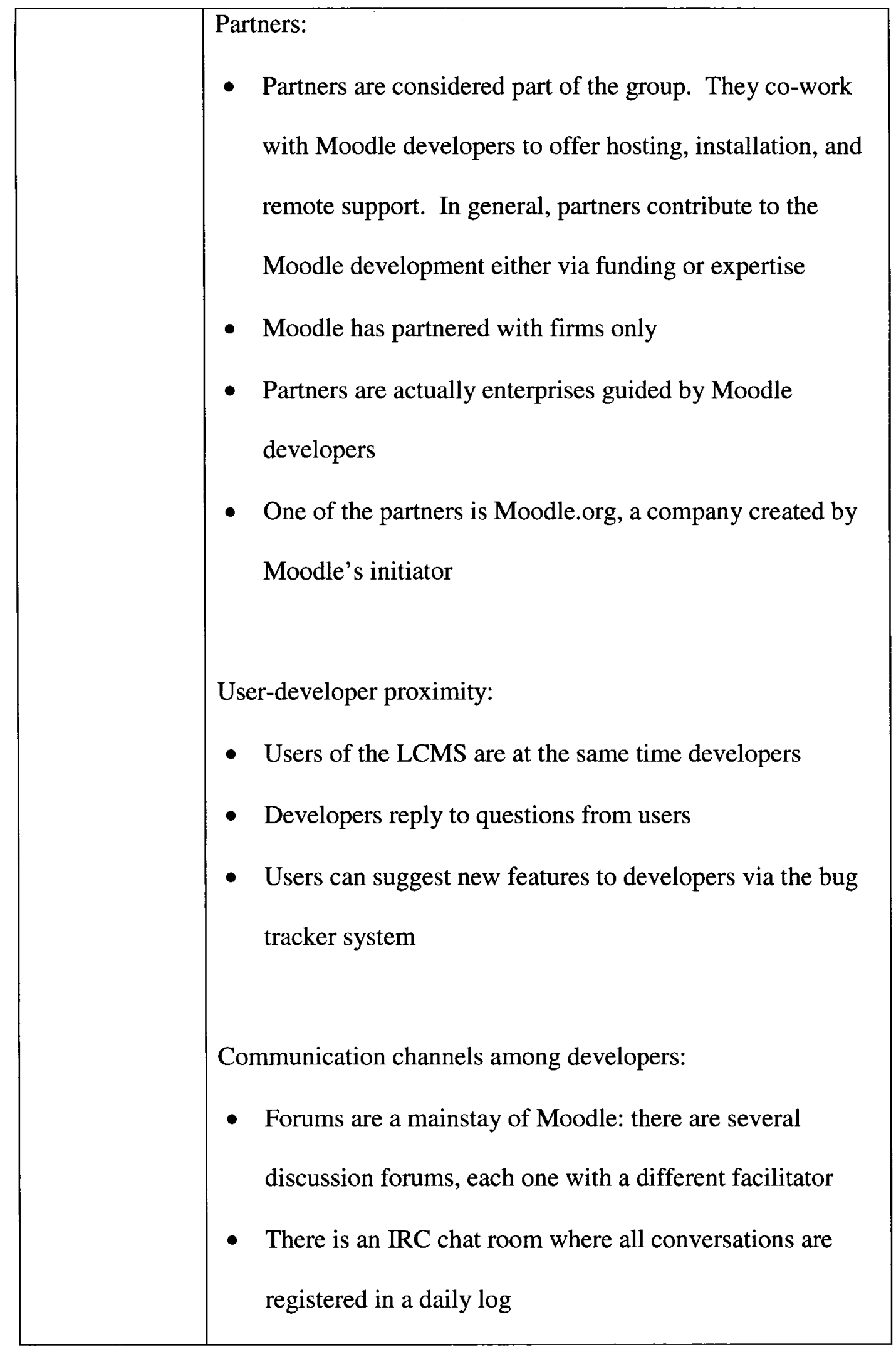


Table 14. Ilias

\begin{tabular}{|c|c|}
\hline $\begin{array}{l}\text { Theoretical } \\
\text { perspective }\end{array}$ & Insights \\
\hline $\begin{array}{l}\text { Communities } \\
\text { of practice }\end{array}$ & $\begin{array}{l}\text { Core mission: } \\
\text { - The mission of this LCMS is to allow users to create, edit } \\
\text { and publish learning and teaching material in a cooperative } \\
\text { fashion } \\
\text { Governance: } \\
\text { - Ilias is governed by a project manager who actually } \\
\text { approves / refuses code commits } \\
\text { Location of the core team: } \\
\text { - Core team is primarily concentrated at the University of } \\
\text { Problem solving (bug reporting): } \\
\text { Bug tracker is an open door not only for bug reporting but } \\
\text { are primarily assigned to experienced developers or to the }\end{array}$ \\
\hline
\end{tabular}




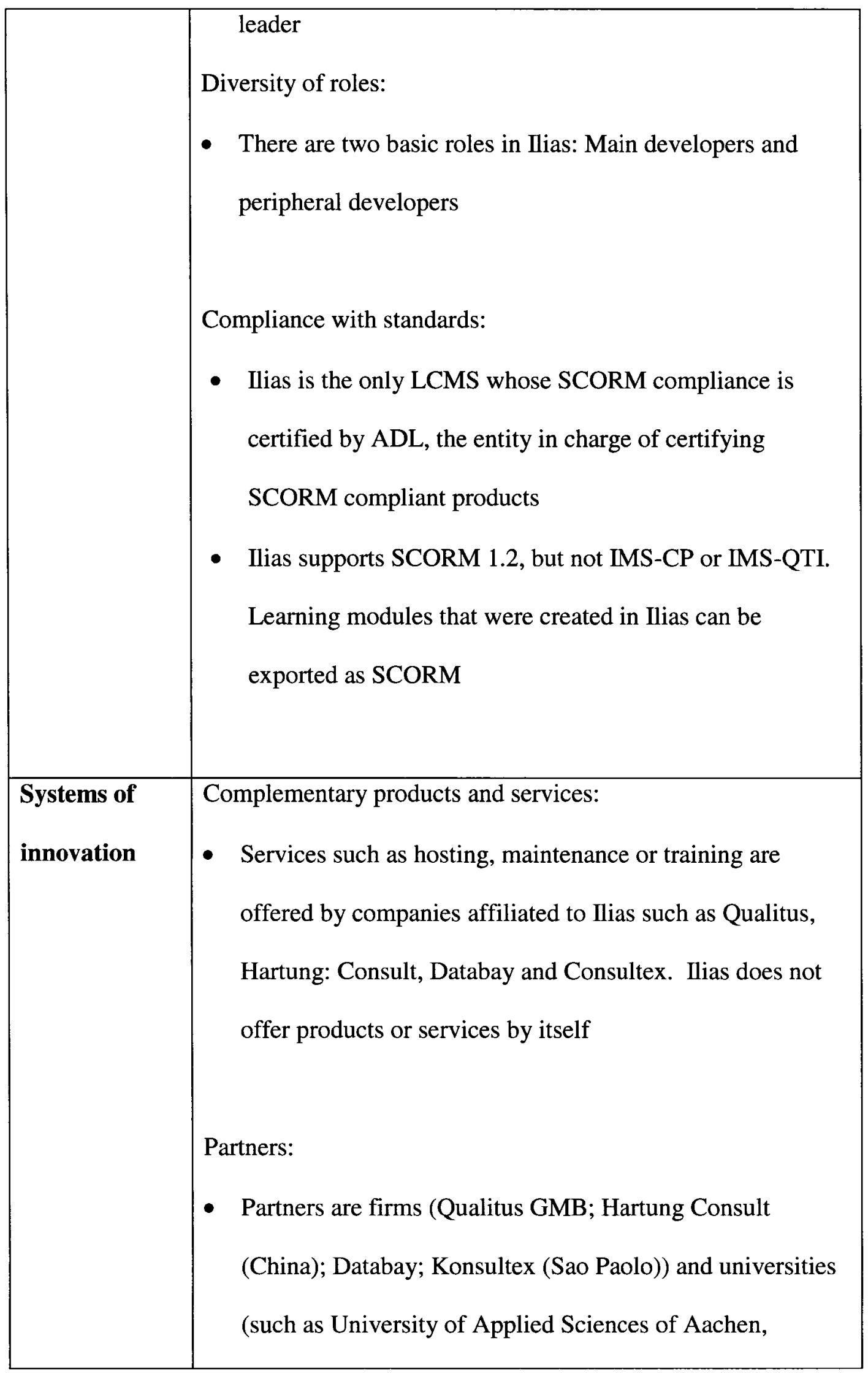




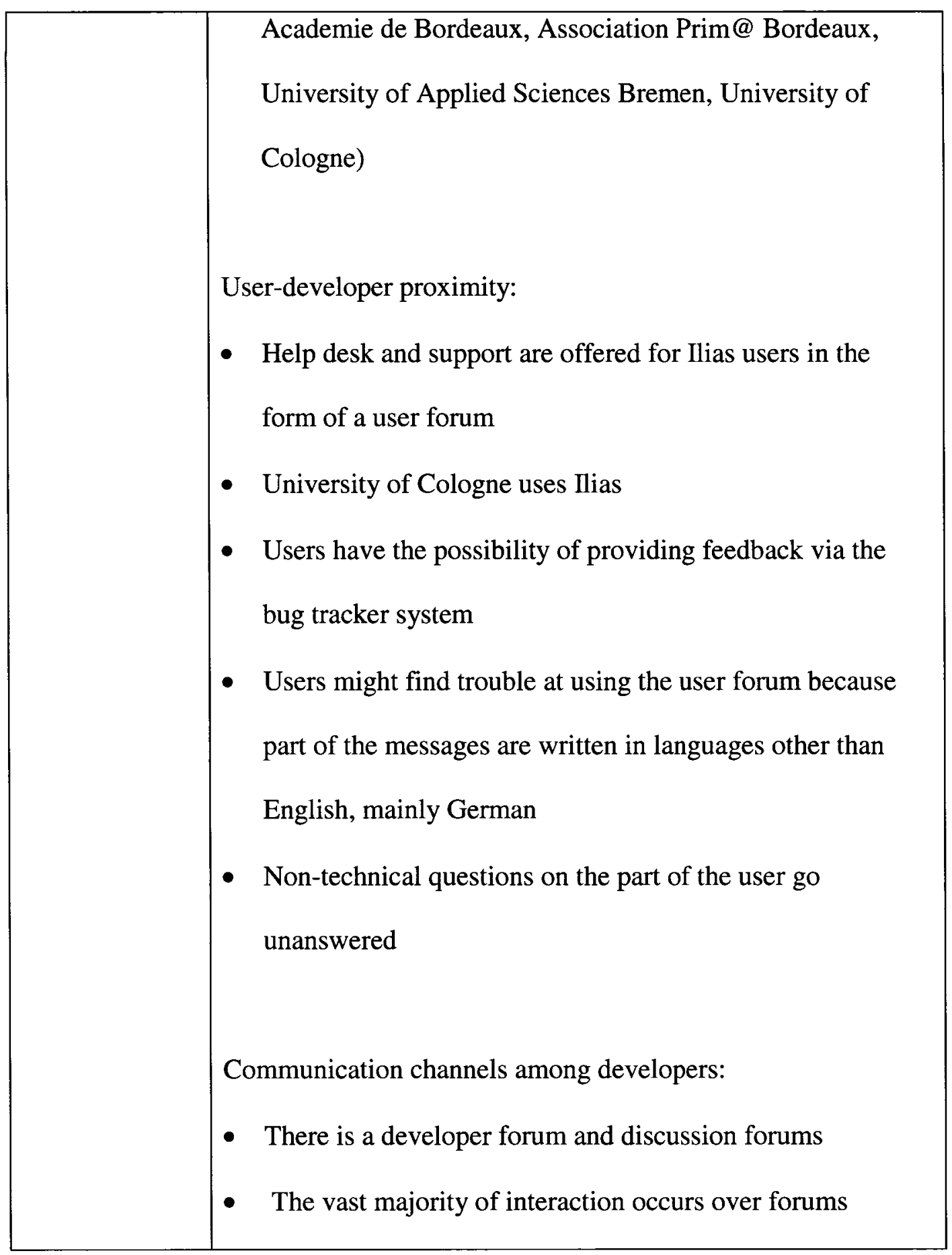


Table 15. ATutor

\begin{tabular}{|c|c|}
\hline $\begin{array}{l}\text { Theoretical } \\
\text { perspective }\end{array}$ & Insights \\
\hline $\begin{array}{l}\text { Communities } \\
\text { of practice }\end{array}$ & $\begin{array}{l}\text { Core mission: } \\
\text { - ATutor is designed with accessibility and adaptability in } \\
\text { mind which makes it particularly suitable for learners, } \\
\text { instructors or administrators with disabilities } \\
\text { Governance: } \\
\text { - The project is led by a Program Manager who answers } \\
\text { most of the questions in the development forums } \\
\text { Location of the core team: } \\
\text { - Core developers are concentrated at the Adaptive } \\
\text { Problem solving (bug reporting): } \\
\text { - Bugs reported often go unnoticed. Those acknowledged } \\
\text { the bug reporting system works as a forum and not as a }\end{array}$ \\
\hline
\end{tabular}




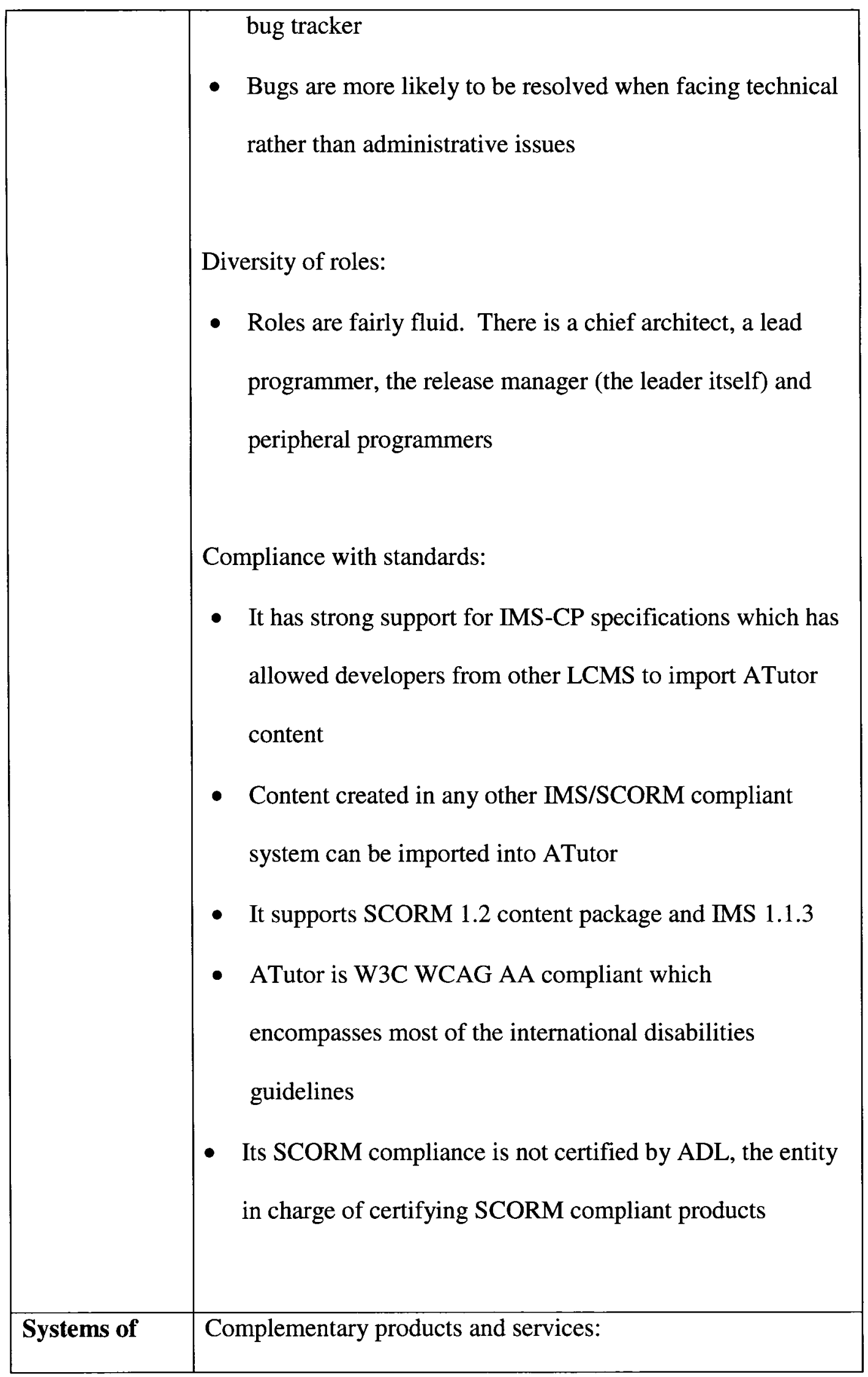




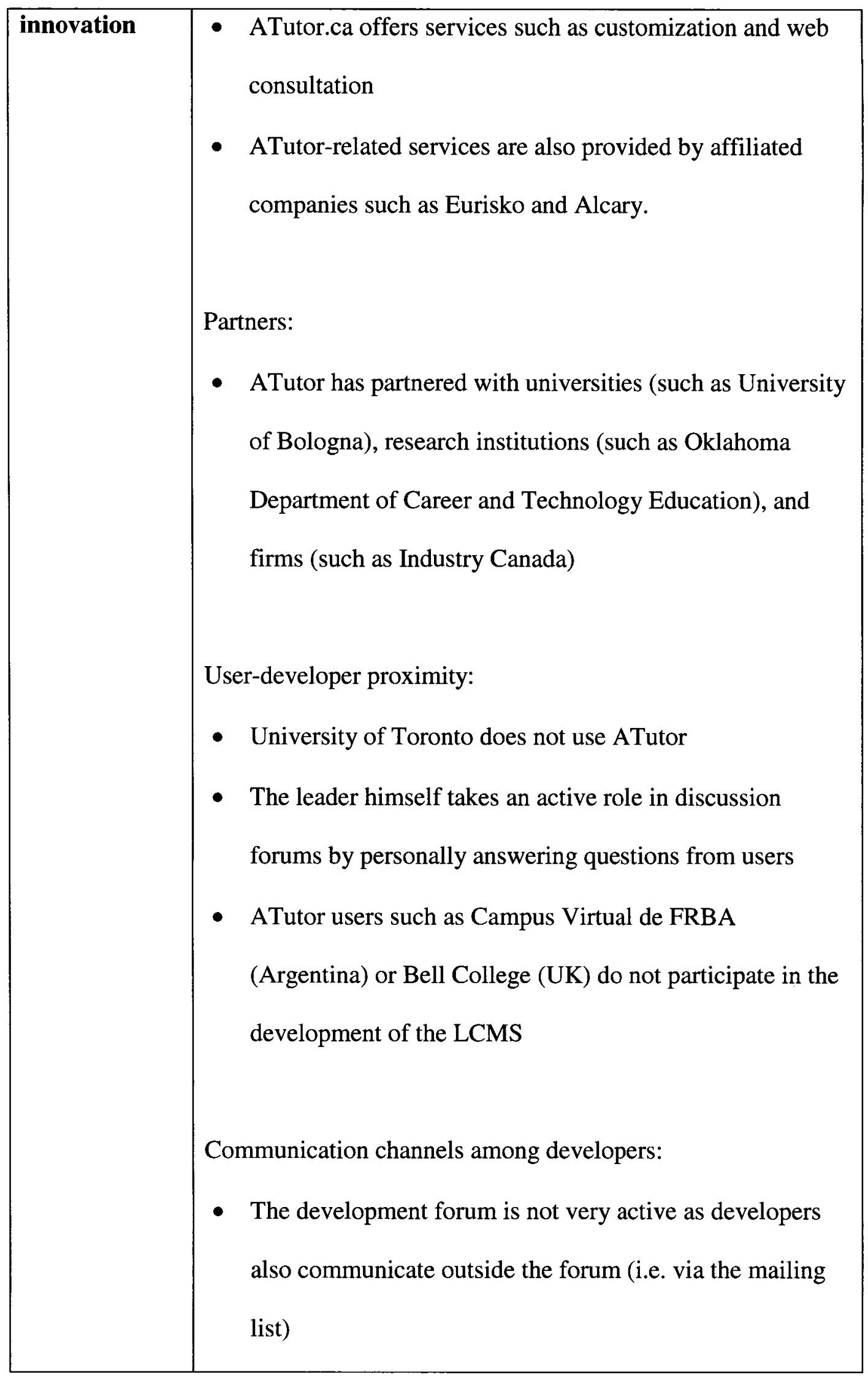


Table 16. Claroline

\begin{tabular}{|c|c|}
\hline $\begin{array}{l}\text { Theoretical } \\
\text { perspective }\end{array}$ & Insights \\
\hline $\begin{array}{l}\text { Communities } \\
\text { of practice }\end{array}$ & $\begin{array}{l}\text { Core mission: } \\
\text { - Claroline offers a particular learning approach motivated } \\
\text { by socio-constructivism and the interaction among } \\
\text { community members } \\
\text { - It recycles entire programs or pieces of code found in the } \\
\text { vast library of the GPL Open Source internet mediated } \\
\text { community } \\
\text { Governance structure: } \\
\text { The head of software is the project board. } \\
\text { Problem solving (bug reporting): } \\
\text { There is a bug tracker. It functions like a forum, so } \\
\text { Core team is concentrated at the University of Louvain } \\
\text { (Belgium) and CERDECAM (Engineering High School in } \\
\text { Belgium) }\end{array}$ \\
\hline
\end{tabular}




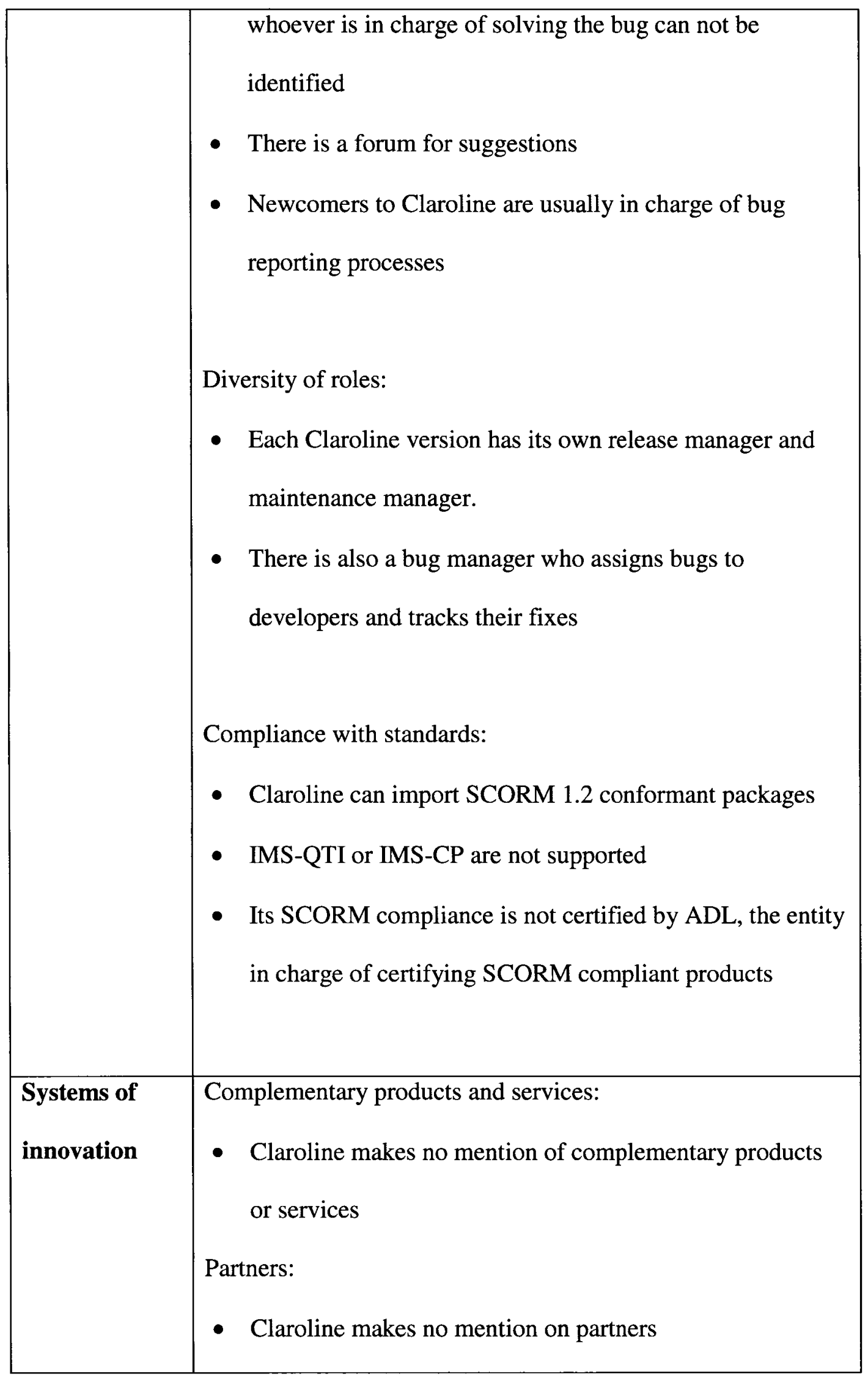


User-developer proximity:

- University of Louvain uses Claroline

- Developers reply to questions from users

Communication channels among developers:

- There is only one forum for communications among developers

- Claroline provides communication tools such as installation and upgrade forums

- Claroline does not offer logs for past communications

Table 17. Olat

\begin{tabular}{|c|c|}
\hline $\begin{array}{l}\text { Theoretical } \\
\text { perspective }\end{array}$ & Insights \\
\hline $\begin{array}{l}\text { Communities } \\
\text { of practice }\end{array}$ & $\begin{array}{l}\text { Core mission: } \\
\text { - Olat is an open source learning content management } \\
\text { system } \\
\text { - Bugs are reported in a project associated to OLAT called } \\
\text { JIRA }\end{array}$ \\
\hline
\end{tabular}




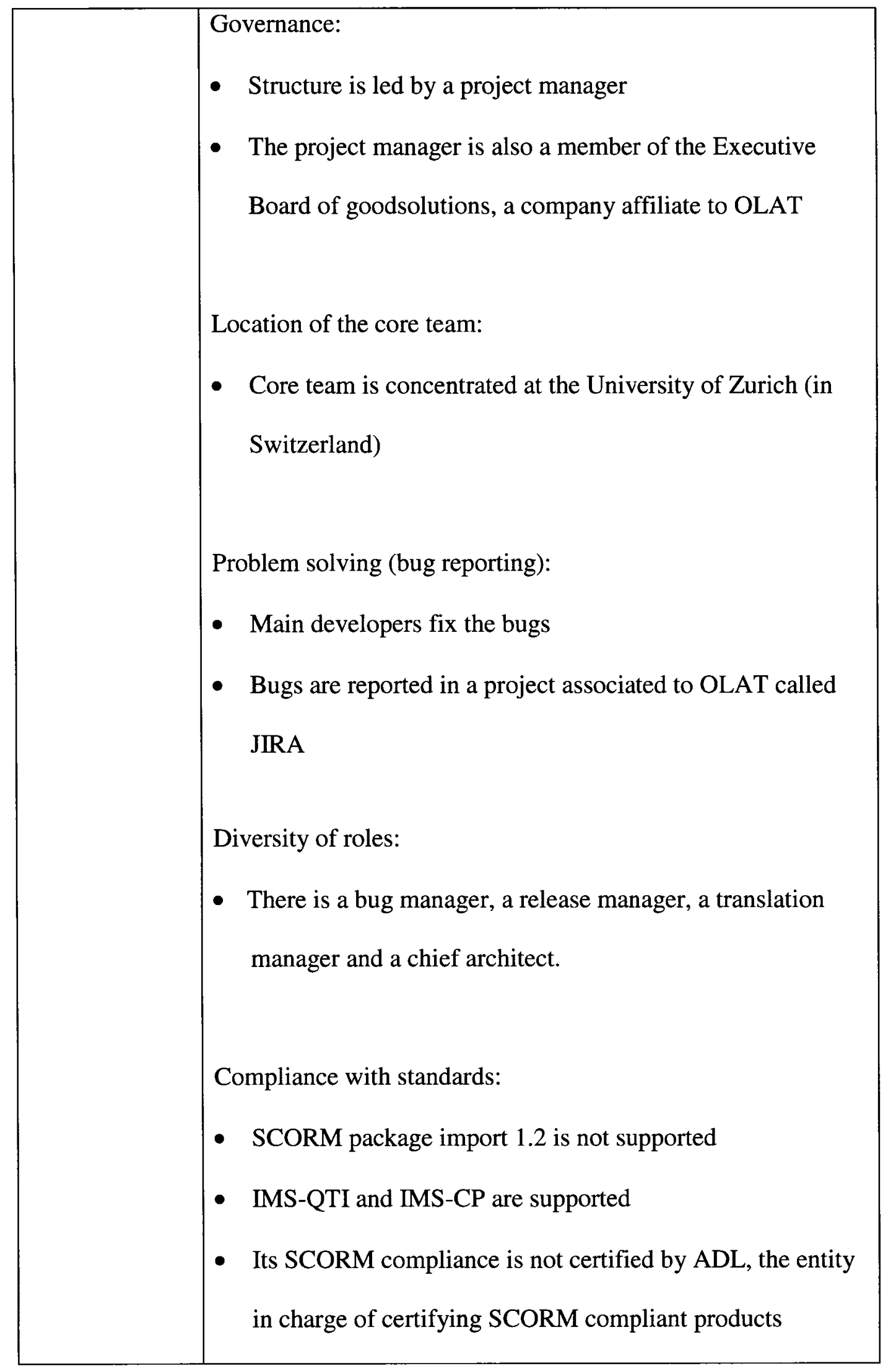




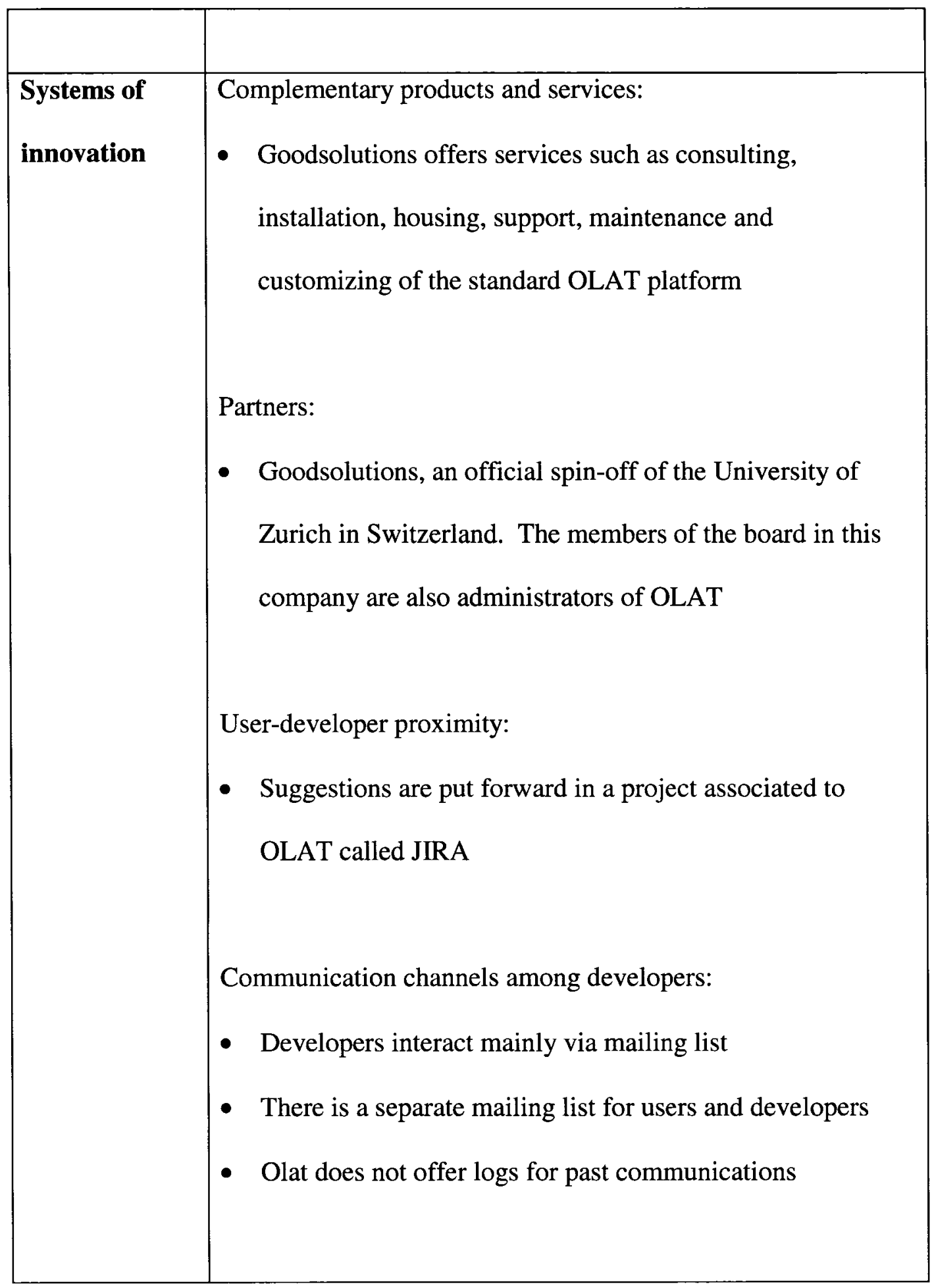


Table 18. Sakai

\begin{tabular}{|c|c|}
\hline $\begin{array}{l}\text { Theoretical } \\
\text { perspective }\end{array}$ & Insights \\
\hline $\begin{array}{l}\text { Communities } \\
\text { of practice }\end{array}$ & $\begin{array}{l}\text { Core mission: } \\
\text { The Sakai Project is a community source software } \\
\text { development effort to design, build and deploy a new } \\
\text { collaboration and learning environment for higher } \\
\text { education } \\
\text { - Structure is led by a project board composed by members } \\
\text { of University of Michigan, Indiana University, MIT, } \\
\text { Location of the core team: } \\
\text { Core team is distributed. Developers are located at the } \\
\text { University of Michigan, Indiana University, Stanford } \\
\text { California-Berkeley and Foothill College } \\
\text { The project has been funded by the Mellon Foundation as } \\
\text { well as by contributions from the Hewlett Packard } \\
\text { Foundation and the core partners (members of the board) } \\
\text { themses }\end{array}$ \\
\hline
\end{tabular}




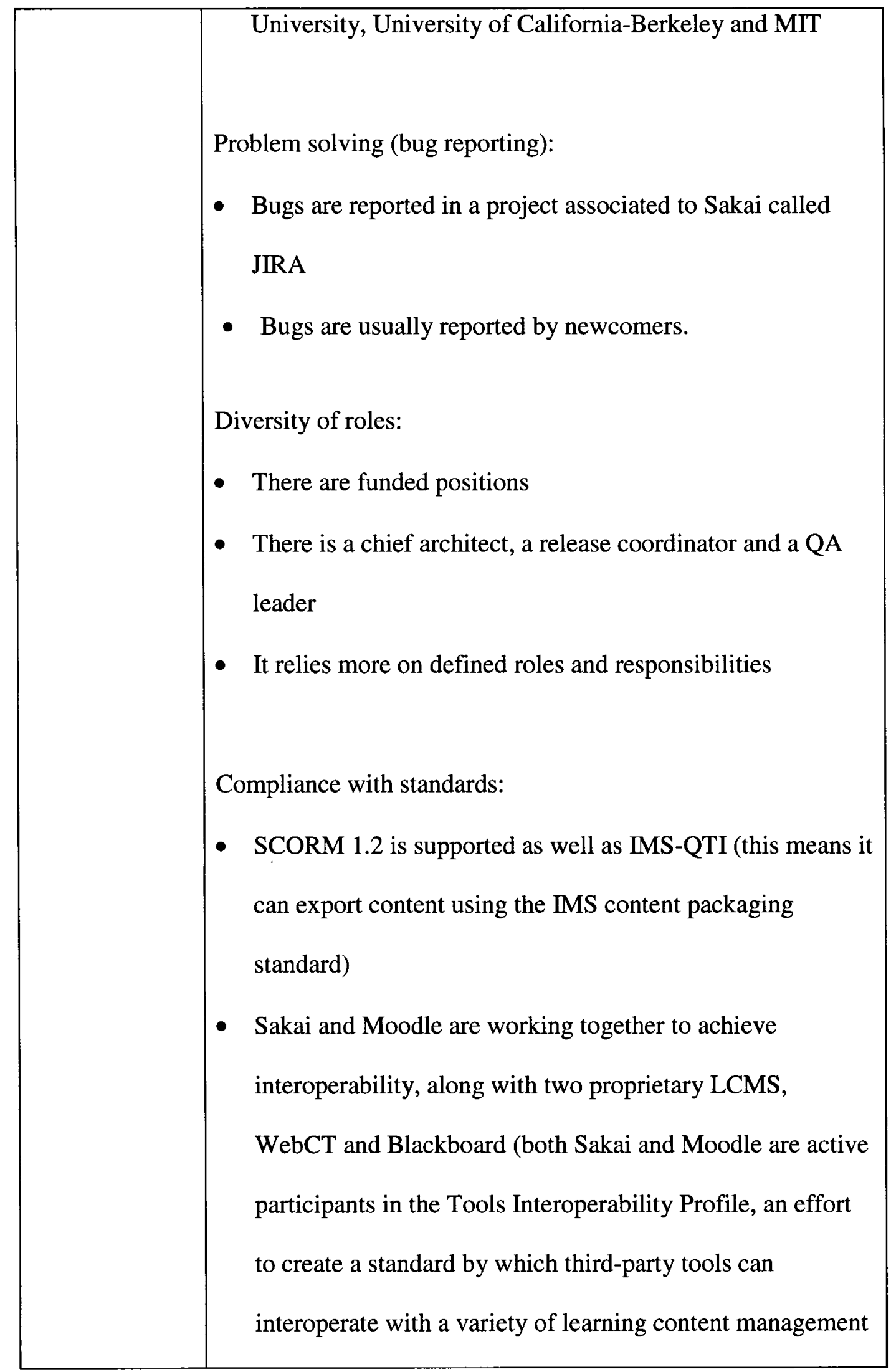




\begin{tabular}{|c|c|}
\hline & $\begin{array}{l}\text { systems) } \\
\text { Its SCORM compliance is not certified by ADL, the entity } \\
\text { in charge of certifying SCORM compliant products }\end{array}$ \\
\hline $\begin{array}{l}\text { Systems of } \\
\text { innovation }\end{array}$ & $\begin{array}{l}\text { Complementary products and services: } \\
\text { - Sakai directly does not offer products or services. There } \\
\text { are some commercial affiliates who do installing, servicing } \\
\text { and consulting around Sakai. } \\
\text { Partners: } \\
\text { - Sakai has partnered with research institutions (such as } \\
\text { Hosei University IT Research Centre), universities (such as } \\
\text { Yale University, MIT, New York University, Princeton } \\
\text { University) and firms (such as Embanet, Harvest road, } \\
\text { IBM, just students, Sun, Unysis, Ostrakon) } \\
\text { Universities developing the LCMS (Michigan, Indiana, } \\
\text { Surrently they do not use Sakai } \\
\text { User-developer proximity: }\end{array}$ \\
\hline
\end{tabular}




\begin{tabular}{|l|l|}
\hline Stanford, Indiana \\
Communication channels among developers: \\
- There is one developer forum for developers to \\
communicate \\
All conversations take place over mailing list; there is not \\
too much conversation on forums \\
Discussions can be viewed by category and thread
\end{tabular}

Table 19. Kewl.NextGen

\begin{tabular}{|l|l|}
\hline \multicolumn{1}{|c|}{ Theoretical } & \multicolumn{1}{c|}{ Insights } \\
of practice & $\begin{array}{l}\text { Kewl.NextGen is a collaboration project whose goal is, } \\
\text { through software development activities, to create } \\
\text { educational and business opportunities that contribute to } \\
\text { development on the African continent. }\end{array}$ \\
$\begin{array}{l}\text { Governance: } \\
\text { The head of the project is the project manager }\end{array}$ \\
$\begin{array}{l}\text { Problem solving (bug reporting): } \\
\text { The bug tracker allows developers to follow up the bug }\end{array}$ \\
\hline
\end{tabular}




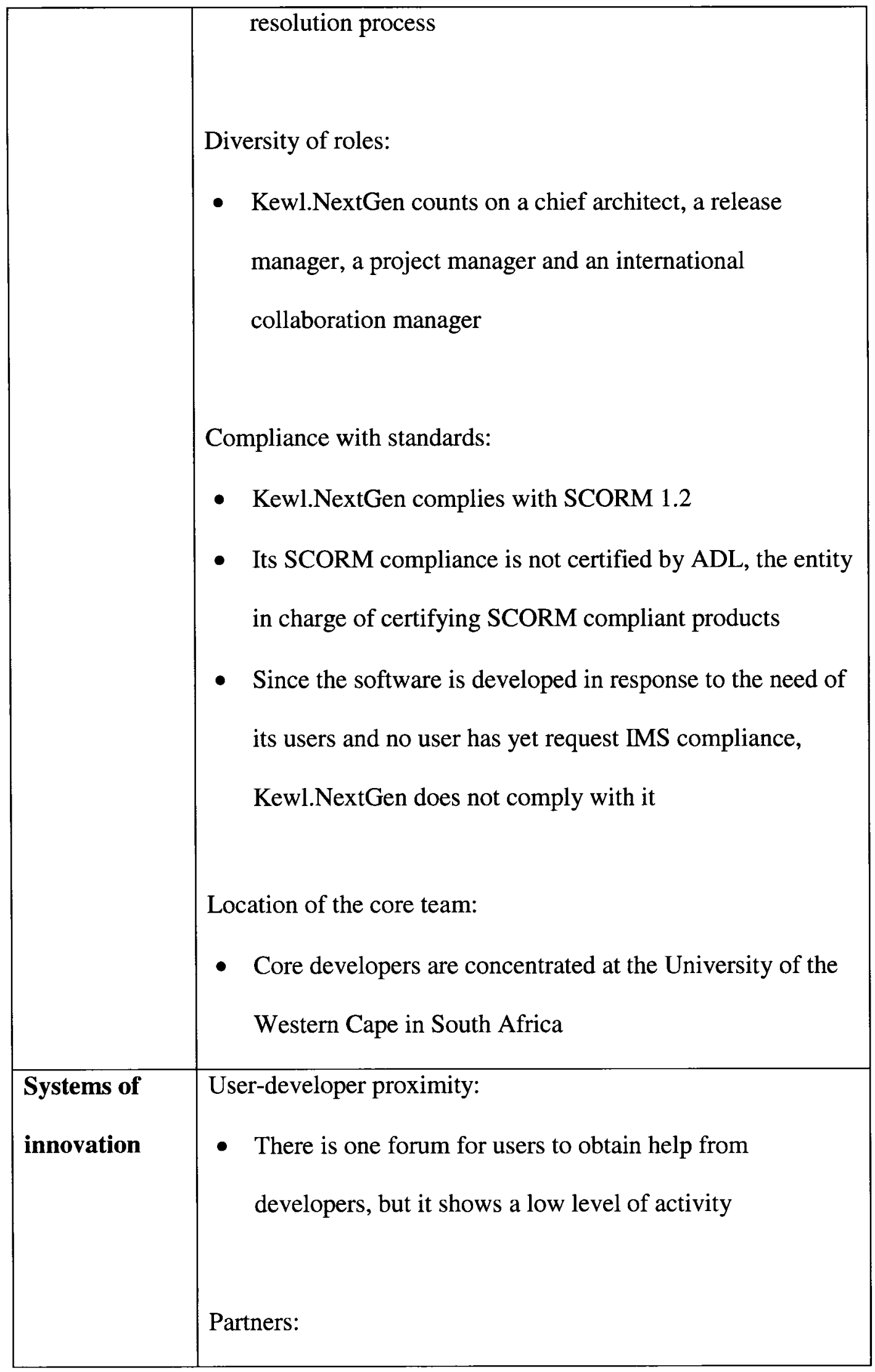




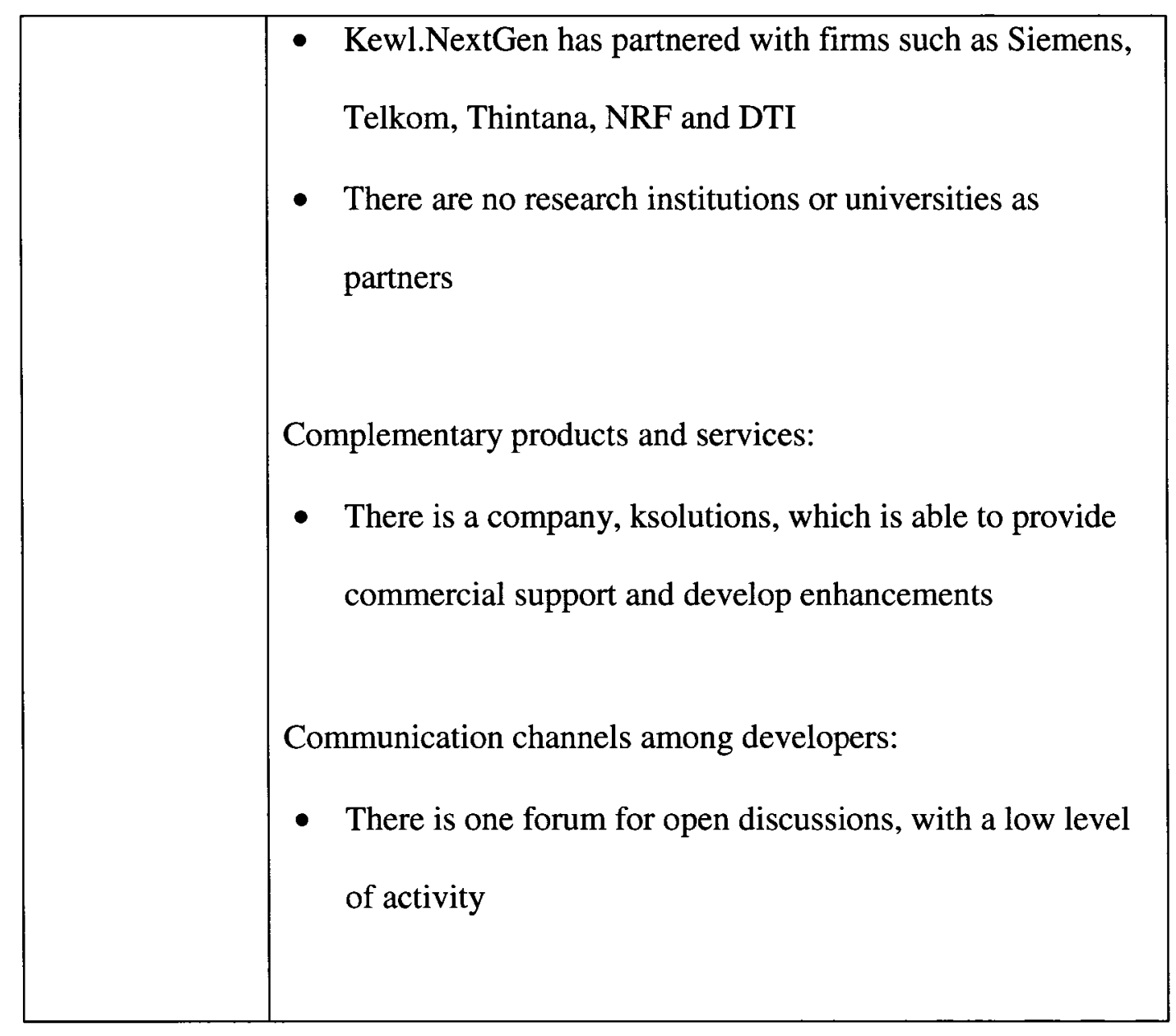

Table 20. Dokeos

\begin{tabular}{|l|l|}
\hline \multicolumn{1}{|c|}{ Theoretical } & \multicolumn{1}{c|}{ Insights } \\
perspective & \\
\hline Communities & $\begin{array}{l}\text { Core mission: } \\
\text { - Dokeos is an Open Source e-learning and course } \\
\text { management web application }\end{array}$ \\
& $\begin{array}{l}\text { Dokeos is also a company helping educational } \\
\text { organizations launch and develop blended learning }\end{array}$ \\
\hline
\end{tabular}




\section{programs}

- Dokeos disagrees with the idea that a learning environment should aim at promoting any special fashion of learning theory. For Dokeos a good tool is as transparent as possible

- Dokeos is a fork from Claroline

Governance:

- The head of the project is the project manager

Problem solving (bug reporting):

- Bugs are reported via the Bug forum

Diversity of roles:

- Dokeos has defined roles such as bug moderator, and in general moderators for every module (Development moderator, FAQ moderator, improvement proposal moderator, translation moderator). However, these roles are not official

Compliance with standards:

- Dokeos has yet to comply with SCORM and IMS-CP, IMS-QTI 


\begin{tabular}{|c|c|}
\hline & $\begin{array}{l}\text { Location of the core team: } \\
\text { - Developers are concentrated in Brussels, Belgium, } \\
\text { anchored around Ghent University }\end{array}$ \\
\hline $\begin{array}{l}\text { Systems of } \\
\text { innovation }\end{array}$ & $\begin{array}{l}\text { User-developer proximity: } \\
\text { - There is one forum in which users can do improvement } \\
\text { proposals or feature requests } \\
\text { - Dokeos is developed and used at Ghent University } \\
\text { - Most of Dokeos's users are located at Ghent University } \\
\text { Partners: } \\
\text { One of the partners is Dokeos, a company created by } \\
\text { Dokeos's initiator } \\
\text { Communication channels among developers: } \\
\text { Complementary products and services: } \\
\text { Dokeos, the company, offers services such as training, } \\
\text { maintenance, migration from proprietary LCMS to } \\
\text { Dokeos and support }\end{array}$ \\
\hline
\end{tabular}


There is a an improvement proposal forum

Table 21. Bazaar

\begin{tabular}{|c|c|}
\hline $\begin{array}{l}\text { Theoretical } \\
\text { perspective }\end{array}$ & Insights \\
\hline $\begin{array}{l}\text { Communities } \\
\text { of practice }\end{array}$ & $\begin{array}{l}\text { Core mission: } \\
\text { - Bazaar is designed with administrators in mind. The goals } \\
\text { are accessibility and simplicity } \\
\text { Governance: } \\
\text { The head of the project is the project board, composed by } \\
\text { members of the Athabasca University } \\
\text { Location of the team: } \\
\text { Core developers are concentrated at Athabasca University } \\
\text { Problem solving (bug reporting): } \\
\text { Bug tracker is located at sourceforge.net } \\
\text { Diversity of roles: }\end{array}$ \\
\hline
\end{tabular}




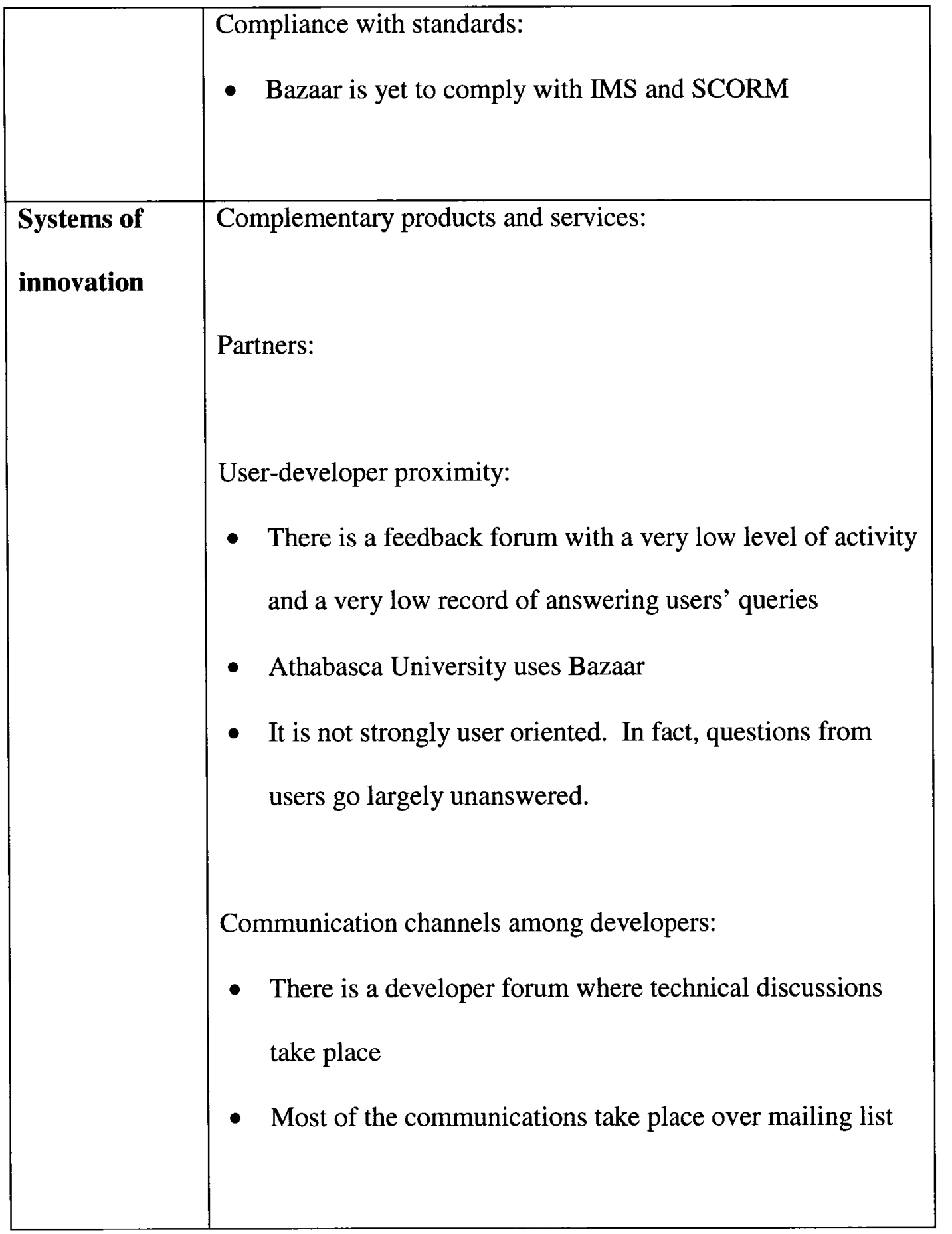


Table 22. Manhattan

\begin{tabular}{|c|c|}
\hline $\begin{array}{l}\text { Theoretical } \\
\text { perspective }\end{array}$ & Insights \\
\hline $\begin{array}{l}\text { Communities } \\
\text { of practice }\end{array}$ & $\begin{array}{l}\text { Core mission: } \\
\text { To provide a fast, stable and effective course management } \\
\text { system } \\
\text { Governance: } \\
\text { There is a project manager who is also the initiator of the } \\
\text { project } \\
\text { Location of the core team: } \\
\text { Core developers are concentrated at the Western New } \\
\text { Diversity of roles: } \\
\text { England College } \\
\text { Problem solving (bug reporting): } \\
\text { programmer / analyst } \\
\text { submitted via the mailing list } \\
\text { - }\end{array}$ \\
\hline
\end{tabular}




\begin{tabular}{|c|c|}
\hline & Compliance with standards: \\
\hline $\begin{array}{l}\text { Systems of } \\
\text { innovation }\end{array}$ & $\begin{array}{l}\text { Complementary products and services: } \\
\text { - Manhattan offers no complementary products or services } \\
\text { Partners: } \\
\text { - Manhattan has no commercial partners } \\
\text { User-developer proximity: } \\
\text { - Western New England College has used Manhattan since } \\
\text { its onset } \\
\text { This LCMS is not strongly user-oriented } \\
\text { - Communications among developers take place over a } \\
\text { Moderators approve/disapprove messages }\end{array}$ \\
\hline
\end{tabular}


Table 23. Eledge

\begin{tabular}{|c|c|}
\hline $\begin{array}{l}\text { Theoretical } \\
\text { perspective }\end{array}$ & Insights \\
\hline $\begin{array}{l}\text { Communities } \\
\text { of practice }\end{array}$ & $\begin{array}{l}\text { Core mission: } \\
\text { Eledge is designed to give educators the electronic edge in } \\
\text { management of online educational and instructional web } \\
\text { sites } \\
\text { Governance: } \\
\text { The head of the project is the project manager, who is also } \\
\text { the initiator of the project } \\
\text { Location of the core team: } \\
\text { - Eledge developers are concentrated at the University of } \\
\text { Problem solving (bug reporting): } \\
\text { Utah }\end{array}$ \\
\hline
\end{tabular}




\begin{tabular}{|c|c|}
\hline & $\begin{array}{l}\text { charge of internationalization } \\
\text { Compliance with standards: }\end{array}$ \\
\hline $\begin{array}{l}\text { Systems of } \\
\text { innovation }\end{array}$ & $\begin{array}{l}\text { Complementary products and services: } \\
\text { - Neither Eledge nor its affiliates offer complementary } \\
\text { products or services } \\
\text { Partners: } \\
\text { - Eledge has not partnered with firms, universities or } \\
\text { research institutions } \\
\text { User-developer proximity: } \\
\text { Eledge is not strongly user oriented } \\
\text { - There are no communication channels among developers }\end{array}$ \\
\hline
\end{tabular}




\section{RESULTS}

This chapter is organized into three sections. The first section provides the insights obtained by examining the 12 projects that develop open source LCMS through the lenses of the two theoretical perspectives, communities of practice and sectoral systems of innovation. The second section suggests propositions that link structure with performance. The last section categorizes the variables that can be used to assess the performance of an open source project developing a LCMS.

\subsection{Insights}

The following insights resulted from using the constructs of the two perspectives used in this research to compare the open source projects in the sample.

\section{Insight 1: In open source LCMS projects there are two types of core missions}

Two different types of core mission were identified in this research: generic and niche. Generic core missions commit the open source project to the advancement of a learning environment using open source software. Examples of open source projects that develop LCMS with generic core missions include Sakai, Ilias, and Manhattan.

The niche type of core mission commits the open source project to support a specific learning approach or address the needs of a particular market segment. Moodle and Claroline are open source projects that promote constructivism as the learning approach. In these environments, learners actively construct new knowledge as they interact with their environments. ATutor is an open source project designed to meet the needs of learners with disabilities. Thus, it is designed with accessibility and adaptability in mind. 


\section{Insight 2: Open source projects have three governance types}

Based on where the leadership function is located, open source projects have three governance types: development project manager, community leader and Board.

Martin Dougiamas is an example of a community leader. He leads the open source project Moodle. He is trusted and respected by a large and diverse global community.

dotLRN, Bazaar, Claroline and Sakai are led by project boards.

Insight 3: Structures of open source project can be operationalized using location of core development team and governance type

Table 24 categorizes the open source projects in the sample based on the location of the core team (concentrated or distributed) and governance type (development project manager, community leader, Board).

The same Table 24 shows that the core developers of 10 of the 12 open source projects in the sample were concentrated at one university or college and that development managers led 7 of the 12 projects.

The core team of the only project led by a community leader (Moodle) was distributed across companies. 
Table 24. Open source projects developing LCMS categorized by location of the core team and governance used

\begin{tabular}{|c|c|c|c|c|}
\hline Location of & $\begin{array}{c}\text { Development } \\
\text { project } \\
\text { manager }\end{array}$ & $\begin{array}{c}\text { Community } \\
\text { leader }\end{array}$ & Board & subtotal \\
\hline $\begin{array}{l}\text { Concentrated at a } \\
\text { university or } \\
\text { college }\end{array}$ & $\begin{array}{l}\text { ATutor, Dokeos, } \\
\text { Eledge, Ilias, } \\
\text { Olat, Manhattan, } \\
\text { Kewl }\end{array}$ & & $\begin{array}{l}\text { DotLRN, } \\
\text { Bazaar, } \\
\text { Claroline }\end{array}$ & 10 \\
\hline $\begin{array}{l}\text { Distributed across } \\
\text { universities }\end{array}$ & & & Sakai & 1 \\
\hline $\begin{array}{l}\text { Distributed across } \\
\text { companies }\end{array}$ & & Moodle & & 1 \\
\hline subtotal & 7 & 1 & 4 & 12 \\
\hline
\end{tabular}

Insight 4: Bug reporting is a strategic activity

Bug reporting activities are at the core of new knowledge generation activities. Bug reporting is deemed to be an important strategic activity. By reporting bugs:

- Newcomers become members of the LCMS structure as the metadata related to every bug provides them with the basic know-how they need to get started and collaborate 
- Users interact with developers

- Software errors get fixed

- Developers are challenged thus finding the motivation they need to stay

- The structure shows proof of ongoing activity

Bug trackers are tools for bug reporting and for making suggestions about new features.

Open source projects such as Moodle report numerous bugs, most of which are closed within days. Other projects such as Manhattan report a very low number of bugs.

\section{Insight 5: Role diversity of an open source LCMS project can be high or low}

Developers in an open source project can take one of several roles (e.g., Chief architect, Release manager, Test manager, Peripheral programmers, Bug manager). High role diversity is preferred. It suggests that the open source project is willing and able to offer developers a variety of ways in which they can contribute to the project. Moodle is an example of an open source project with high role diversity. It supports many different roles. Bazaar is an example of an open source project with low role diversity. It supports one role, that of the development leader.

\section{Insight 6: Standard compliance varies widely}

Standards provide members with learning opportunities. Standards compliance varies widely across open source projects producing the same generic product. 
Open source projects comply with standards when doing so is seen to be part of their core

mission. For example, ATutor complies with standards because doing so is perceived as being part of its core mission of serving disabled users. ATutor complies with standards such as IMS, SCORM and W3C WCAG AA. Standard compliance attracts users of certain type.

Most open source projects do not comply with many standards. Standard compliance is not seen to be important to the fulfillment of their core mission or users have not requested that the open source project comply to standards.

\section{Insight 7: Structure affects performance}

Open source projects that perform better have a community leader and a distributed core development team.

The development teams of some open source projects are concentrated around universities such as ATutor (University of Toronto), Ilias (University of Cologne), dotLRN (MIT Sloan School of Management) and Claroline (University of Louvain) or around colleges such as Manhattan (Western New England College). However open source projects that rank high in terms of performance have a distributed development team and are led by a community leader. The core developers of Moodle are distributed around the world, they are not concentrated at a university or college. Moodle performs better in terms of the three performance indicators used in this research: number of releases, number of users / downloads and number of developers. Moodle released five 
stable versions of their source code during the period May 2003 to May 2005 leading all other open source projects in the sample.

\section{Insight 8: Partner diversity influences performance}

Open source projects have partners. For example, dotLRN's partners actively participate in the development process as some partners are also users. Partners then work in parallel to advance new features or new tools that are later on adopted by the core team members. Partners of Moodle, Ilias and Sakai offer hosting, installation and remote support to the open source projects.

Sakai and Moodle have a large number of partners and high partner diversity. Claroline does not have partners. Open source projects with high partner diversity tend to perform better than open source projects with low partner diversity.

\section{Insight 9: Open source projects have commercial interests}

Open source projects such as dotLRN, Moodle, Dokeos and Sakai offer products and services for sale through their commercial affiliates. Other open source projects do not have any commercial affiliations. Open source projects with commercial interests perform better than those that do not have commercial interests. 


\section{Insight 10: Communication channels transform tacit into explicit knowledge that becomes the project's memory}

Developer forums are the preferred means to exchange technical knowledge in open source projects. Communication brings visibility to the development process as in some cases communications are captured in electronic form thus turning into the virtual community memory. The number of communication channels relates to the flow of information among developers. The greater the communication flow, the greater the number of communication channels.

The vast majority of interactions occur over mailing list in the case of concentrated structures such as dotLRN and ATutor. This, in fact, does not add visibility to the communications. In cases such as Moodle, forums are a mainstay: there are several discussion forums per topic, each one with a different facilitator, thus being easier to attract new developers.

In the case of Moodle, designers have put effort to keep developers together by providing nine development forums. In each forum, developers can report issues, announce latest features, mention new code tested or discuss general issues in different languages, among all. In contrast, concentrated structures such as dotLRN, Ilias, ATutor, Claroline and Olat offer only one forum where developers can exchange ideas and expertise. 
5.2 Propositions that link structure and performance of open source projects

Figure 5 illustrates the model that anchors propositions 1 to 10 while Figure 6 illustrates the model that anchors propositions 11 to 17 . Table 25 provides the data that supports the development of the propositions.

Table 25. Structure - performance of open source projects

\begin{tabular}{|c|c|c|c|c|c|}
\hline \multirow[b]{2}{*}{$\begin{array}{c}\text { Concentrated } \\
\text { or } \\
\text { distributed }\end{array}$} & \multirow[b]{2}{*}{ Who leads } & \multirow[b]{2}{*}{$\begin{array}{c}\text { LCMS in } \\
\text { sample }\end{array}$} & \multicolumn{3}{|c|}{ Performance } \\
\hline & & & $\begin{array}{c}\text { Average } \\
\text { number of } \\
\text { releases }\end{array}$ & $\begin{array}{l}\text { Average } \\
\text { number of } \\
\text { downloads / }\end{array}$ & $\begin{array}{l}\text { Average } \\
\text { number of } \\
\text { developers }\end{array}$ \\
\hline \multirow[t]{2}{*}{$\begin{array}{l}\text { Concentrated at } \\
\text { University or } \\
\text { college }\end{array}$} & $\begin{array}{l}\text { Development } \\
\text { project } \\
\text { manager }\end{array}$ & $\begin{array}{l}\text { Ilias, ATutor, } \\
\text { Olat, } \\
\text { Kewl.NextGen, } \\
\text { Dokeos, } \\
\text { Manhattan, } \\
\text { Eledge }\end{array}$ & 2.42 & 4681 & 7.285 \\
\hline & Board & $\begin{array}{l}\text { dotLRN, } \\
\text { Bazaar, } \\
\text { Claroline }\end{array}$ & 2.666 & 13124.3 & 10.66 \\
\hline $\begin{array}{l}\text { Distributed } \\
\text { across } \\
\text { universities }\end{array}$ & Board & Sakai & 3 & 84000 & 36 \\
\hline Distributed & Community & Moodle & 5 & 65725 & 129 \\
\hline
\end{tabular}




\begin{tabular}{|l|l|l|l|l|l|}
\hline across small & Leader & & & & \\
companies & & & & & \\
\hline
\end{tabular}

\section{Figure 5. Model originating propositions 1 to 10}

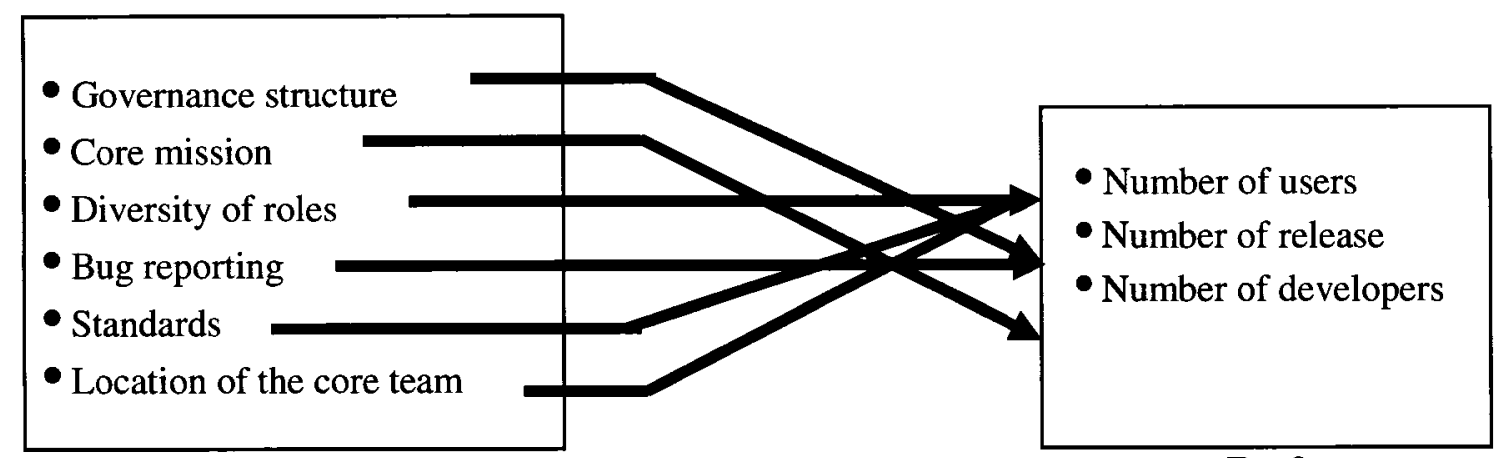

Communities of Practice

Performance

\section{Proposition 1}

Number of users is greater for concentrated open source projects led by a board than concentrated open source projects led by a project manager.

\section{Proposition 2}

Number of releases is greater for open source projects led by a community leader than open source projects led by a board.

\section{Proposition 3}

Number of developers is greater for open source projects with niche missions than those with generic missions. 


\section{Proposition 4}

High role diversity is positively associated with the performance of open source projects.

\section{Proposition 5}

Number of releases is greater for open source projects reporting a greater number of bugs.

\section{Proposition 6}

Number of users is greater for concentrated open source projects that adhere to standards than concentrated open source projects that do not.

\section{Proposition 7}

Number of releases is greater for distributed open source projects than concentrated open source projects.

\section{Proposition 8}

Number of developers is greater for distributed open source projects than concentrated open source projects.

\section{Proposition 9}

Number of users is greater for distributed open source projects than concentrated open source projects. 


\section{Proposition 10}

Open source projects whose headquarter uses the software perform better than those that do not.

\section{Figure 6. Model originating propositions 11 to 17}

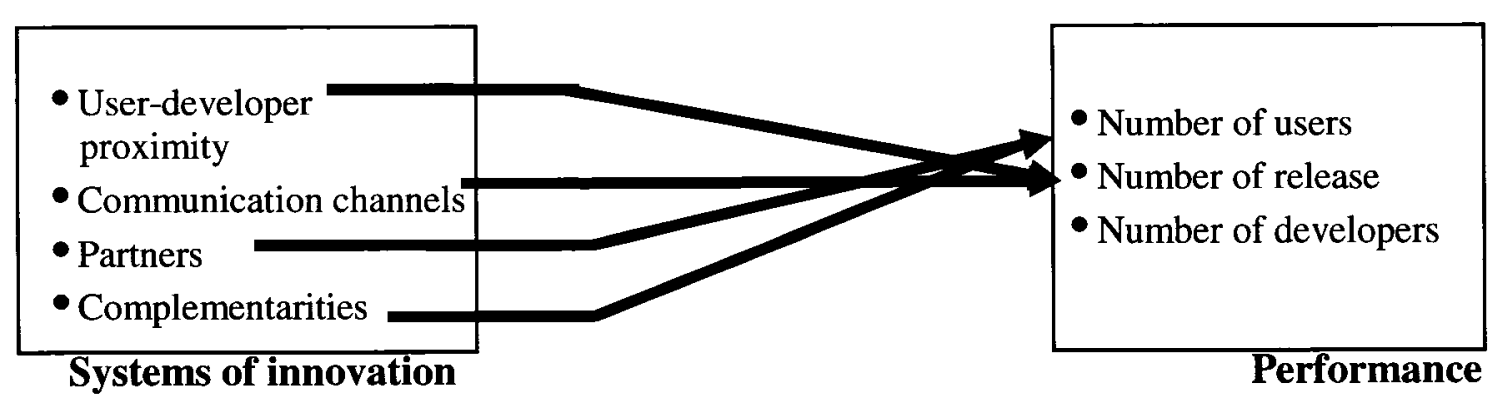

\section{Proposition 11}

Number of software releases is greater for open source projects with high user-developer proximity.

\section{Proposition 12}

Number of users is greater for open source projects with high user-developer proximity.

\section{Proposition 13}

Number of developers is greater for open source projects offering a greater number of communication channels. 


\section{Proposition 14}

Number of releases is greater for open source projects offering a greater number of communication channels.

\section{Proposition 15}

Number of developers is greater for open source projects offering a higher visibility in their communications.

\section{Proposition 16}

Number of users is greater for concentrated open source projects with high partner diversity.

\section{Proposition 17}

Number of users is greater for open source projects that offer complementary products and services for sale than those that do not.

5.3 Variables that can be used to assess the performance of a structure developing open source LCMS

From the research on the relationship between structure and performance of open source LCMS projects, the following variables can be suggested to assess performance:

\section{(i) Communities of practice}

- Structure follows a particular learning approach 
- Structure pursues a particular market niche

- Governance corresponds to a community leader

- Presence of a distributed core team

- High number of bugs reported

- High number of different roles

- If core team is concentrated, compliance with IMS standard

- If core team is concentrated, compliance with SCORM standard

\section{(ii) Systems of innovation}

- Number of complementary products offered by the structure developing LCMS

- Number of complementary services offered by the structure developing LCMS

- If core team is concentrated, high number of partners

- If core team is concentrated, high variety of partners

- Numbers of forums through which users and developers can interact

- Users have the skills to provide adequate feedback to developers

- Number of communication channels for developers

- Visibility of the communication channels for developers 


\section{CONCLUSIONS, RECOMMENDATIONS, LIMITATIONS AND SUGGESTIONS FOR FUTURE RESEARCH}

This chapter is organized into five sections. The first section provides the conclusions of this research. The second section provides recommendations to managers wishing to establish open source projects. The suggestions to improve performance of open source software are presented in section three. The fourth section describes the limitations of this study. Finally, the fifth section provides suggestions for future research.

\subsection{Conclusions}

The objective of this research was to examine the relationship between the structure of a project that develops open source software and the project's performance measured as the number of releases per year, number of downloads, and number of developers producing the software.

Data on twelve learning content management systems was used to examine the structureperformance relationship of open source projects.

The outputs of this research include: (i) write-ups on twelve open source projects that develop LCMS, (ii) ten insights obtained from examining the structure-performance relationship of twelve LCMS using constructs from two theoretical perspectives, communities of practice and systems of innovation, (iii) seventeen propositions anchored around two models for the relationship between structure and performance of LCMS and (iv) set of variables that can be used to assess the performance of open source projects. 
The communities of practice framework was not easy to apply. To date most applications of this framework were in the field of sociology. The use of this framework in this research required the difficult task of operationalizing the framework's constructs using dimensions relevant to open source projects.

The literature suggests that the core teams of open source projects are generally distributed (Mockus, Fielding and Herbsleb, 2002). This was found not to be the case for LCMS. The core development teams of ten of 12 open source projects that develop LCMS are concentrated in colleges or universities.

When performance is measured in terms of number of developers and number of releases, the open source projects that perform better are those led by a community leader with a distributed development team. The community of practice perspective provides a good explanation as to the reasons why these structures perform better relative to others.

Successful open source projects have a clear governance structure. This is in contrast with the extant literature that describes open source communities as chaotic and anarchic (van Wendel de Joode, de Bruijn, and van Eeten, 2002).

The main challenge of open source communities is not technical. The challenge is how to maintain developers working together and how to keep users interested in the software. 
Successful open source projects make it easy for developers to connect with each other and for users to access the information from the community's knowledge base.

\subsection{Recommendations for setting up OSS projects}

To managers wishing to set up open source projects, the following recommendations are offered:

- Provide developers with reasons to continuously contribute to the OSS project. To stay, developers must have a challenge (user requirements, bugs) and a clear path to follow that is consistent with the core mission

- Provide a credible community leader to the open source project. The leader must be trusted and technically proficient

- Provide users of the software produced with the skills / tools to provide effective feedback

- Enable many and different ways for users to interact among themselves (FAQ, discussion forums, IRC chat, mailing lists and other asynchronous communications)

\subsection{Suggestions to improve the performance of open source projects}

This section provides suggestions on how to improve the performance of open source projects.

To increase the number of developers who will contribute code, define the core mission of the open source project around a particular learning methodology or niche application. 
For example, Moodle and Claroline define their core missions around constructivism and dynamic learning as learning approaches and ATutor defines its core mission around users with disabilities

To increase the number of releases, provide a powerful community leader, increase the number and diversity of communication channels, increase the motivation to test and post bug reports, and use the software at the institution where project headquarters is located.

To increase the number of users, increase the number of commercial products and services offered as well as the diversity of roles the project supports.

Table 26 summarizes the structural factors and the likeliness of success.

Table 26. Factors that increase the likelihood of open source project success

\begin{tabular}{|l|l|l|l|}
\hline \multicolumn{1}{|c|}{$\begin{array}{c}\text { Open source projects } \\
\text { are more successful } \\
\text { when }\end{array}$} & \multicolumn{1}{|c|}{ Example } & Open source & \\
structures are less & \multicolumn{1}{c|}{ Example } \\
successful when & \\
particular learning & ATutor, & Core mission is generic & dotLRN, Ilias \\
approach & Claroline & & \\
\hline Project is led by & Moodle & Project is led by a & dotLRN, \\
community leader & & Board & Claroline \\
\hline
\end{tabular}




\begin{tabular}{|c|c|c|c|}
\hline $\begin{array}{l}\text { A high number of bugs } \\
\text { is reported }\end{array}$ & Moodle & $\begin{array}{l}\text { A low number of bugs } \\
\text { is reported }\end{array}$ & $\begin{array}{l}\text { Bazaar, } \\
\text { Manhattan, } \\
\text { Eledge }\end{array}$ \\
\hline $\begin{array}{l}\text { There is a high diversity } \\
\text { of roles }\end{array}$ & Moodle, Sakai & $\begin{array}{l}\text { There is a low diversity } \\
\text { of roles }\end{array}$ & Eledge \\
\hline Core team is distributed & Moodle, Sakai & $\begin{array}{l}\text { Core team is } \\
\text { concentrated }\end{array}$ & $\begin{array}{l}\text { Manhattan, } \\
\text { Bazaar, } \\
\text { dotLRN, Eledge }\end{array}$ \\
\hline $\begin{array}{l}\text { There is a high number } \\
\text { of partners involved }\end{array}$ & $\begin{array}{l}\text { DotLRN, } \\
\text { ATutor }\end{array}$ & $\begin{array}{l}\text { There is a low number } \\
\text { of partners involved }\end{array}$ & Dokeos, Bazaar \\
\hline $\begin{array}{l}\text { Commercial products or } \\
\text { services are offered by } \\
\text { organizations controlled } \\
\text { by the leaders of the } \\
\text { project }\end{array}$ & $\begin{array}{l}\text { Moodle, } \\
\text { Dokeos }\end{array}$ & $\begin{array}{l}\text { Commercial products or } \\
\text { services are either not } \\
\text { offered or are offered } \\
\text { by organizations } \\
\text { affiliated to the project }\end{array}$ & Sakai, Claroline \\
\hline $\begin{array}{l}\text { There is large number } \\
\text { of communication } \\
\text { channels among } \\
\text { developers }\end{array}$ & Moodle & $\begin{array}{l}\text { There is a low number } \\
\text { of communication } \\
\text { channels among } \\
\text { developers }\end{array}$ & Bazaar \\
\hline $\begin{array}{l}\text { Institution that houses } \\
\text { the headquarters of the } \\
\text { open source project } \\
\text { uses its LCMS }\end{array}$ & Ilias, Claroline & $\begin{array}{l}\text { Institution that houses } \\
\text { the headquarters of the } \\
\text { open source project } \\
\text { does not use its LCMS }\end{array}$ & ATutor \\
\hline
\end{tabular}




\subsection{Limitations}

This research has at least two limitations. First, not all open source projects have the same longevity. Thus, more data is available for projects that have been around longer.

The second limitation is that data were gathered from websites. Thus, the researcher may have misrepresented the meaning of the data on the website.

\subsection{Suggestions for future research}

There are four suggestions for future research. First, the suggested propositions can be tested for a sample comprised of open source LCMS.

Second, the results of this study can be validated using samples that include open source projects that develop software other than LCMS.

Third, researchers can assess potential differences between open source and product development in terms of location of core team and communications.

Fourth, to capture the distinctness of open source software development, researchers can compare alternative modes of collective production namely open source and proprietary software development, thus revealing necessary conditions for its functioning as well as specific advantages of each one. 


\section{REFERENCES}

Ahmed, O. 2005. Migrating from proprietary to open source learning content management systems. Unpublished master dissertation, Carleton University, Ottawa.

Bonaccorsi, A. and Rossi, C. 2003. Why open source software can succeed. Research Policy, 32 (7): 1244-1258.

Braczyk, H. J., Cooke, P., and Heidenreich, M. 1998. Regional Innovation Systems: The governances in a globalized world, after 20 years. London: University College London

Brennan, C., Funke, S., and Anderson, C. 2001. "The learning content management system”. White Paper, URL:

http://www.trainingfoundation.com/tfimages/ftp/IDCLCMSWhitePaper.pdf (accessed on October 15, 2005).

Breschi, S., and Malerba, F. 1997. Sectoral innovation systems: Sectoral regimes, Schumpeterian dynamics, and spatial boundaries. In: C. Edquist (Ed.), Systems of Innovation: Technologies, institutions and organizations. London: Pinter.

Brown, S.L., and Eisenhardt, K.M. 1995. Product development: Past research, present findings and future directions. Academy of Management Review, 20 (2): 343-378. 
Carlsson, B., S. Jacobsson, M. Holmen, and Rickne, A. 2002. Innovation systems: Analytical and methodological issues. Research Policy, 31 (2): 233-245.

Carlsson, B., and Stankiewicz, R. 1991. On the nature, function, and composition of sectoral systems. Journal of Evolutionary Economics, 1 (2), 93-118.

Cavalier, F. 1998. "Some implications of bazaar size". URL:

http://www.mibsoftware.com/bazdev (accessed August 26, 2005).

Coppola, C., and Neely, E. 2004. “Open source - open learning”. URL:

www.rsmart.com (accessed on November 1, 2005).

Cornejo, M. 2004. “The community of practice ecosystem”. URL:

http://www.knowledgeboard.com/cgi-bin/library.cgi?action=detail\&id=3643 (accessed May 25, 2005).

Crowston, K., and Howison, J. 2004. "The social structure of free and open source software development". Research working paper. URL: http://floss.syr.edu (accessed on December 10, 2005).

Crowston, K., and Howison, J. 2005. “A portfolio of FLOSS project success measures. Research working paper". URL: http://floss.syr.edu/StudyP/Crowston2005APortfolio.pdf (accessed on December 10, 2005). 
Donnello, J. 2002. “Theory and Practice: Learning Content Management System, Knowledge System news”. URL: http://www.leadingway.com/nlback/Newsletter07_19_02.htm (accessed May 6, 2005)

Edquist, C., and Johnson, B. 1997. Institutions and organizations in systems of innovation. In C. Edquist (Ed.), Systems of Innovation: Technologies, institutions and organizations. London: Pinter.

Eisenhardt, J. N. 1989. Building theories from case study research. Academy of Management Review, 14 (4): 532-550.

Eliasson, G., and Eliasson, A. 1996. The biosectoral competence bloc. Revue d'Economie Industrielle, 78 (4): 7-26.

Gabbay, J., Le May, A., Jefferson, H., Webb, D., Lovelock, R., Powell, J., and Lathlean, J. 2003. A case study of knowledge management in multiagency consumer-informed Communities of practice: Implications for evidence-based policy development in health and social services. Illness and Medicine, 7 (3): 283-310.

Geels, F. 2004. From sectoral systems of innovation to socio-technical systems: Insights about dynamics and change from sociology and institutional theory. Research Policy, 33 (6-7): 897-920. 
Gongla, P., and Rizzuto, C. R. 2004. Where did that community go? In P. Hildreth and C. Kimble (Eds.), Knowledge networks. Hershey, PA: Idea group.

Holmes, J. 1999. The communities of practice: Theories and methodologies in language and gender research. Language in Society, 28 (2): 173-183.

Howard, P. 2002. Network ethnography and the hypermedia organization: New media, new organizations, new methods. New Media and Society, 4 (4): 550-574.

Ismail, J. 2002. The design of an e-learning system: Beyond the hype. The Internet and Higher Education, 4 (3-4): 329-336.

Johnson, C. 2001. A survey on current research on online communities of practice. The Internet and Higher Education, 4 (1): 45-60.

Krishnamurthy, S. 2002. "Cave or Community: An empirical Examination of 100 Mature Open Source Projects", URL:

http://www.firstmonday.dk/issues/issue 7 6/krishnamurthy/ (accessed on June 14, 2005).

Krishnan, V., and Ulrich, K. 2001. Product development decisions: A review of the literature. Management Science, 47 (1): 1-21. 
Larson, E., and Gobeli, D. 1989. Significance of project management structure on Development Success. IEEE Transactions on Engineering Management, 36 (2): 119-125. Lancashire, D. 2001. "Code, culture and cash: The fading altruism of open source development". URL: http://www.firstmonday.org/issues/issue6 12/lancashire (accessed on January 5, 2006)

Lave, J., and Wenger, E. 1991. Situated learning: Legitimate peripheral action. Cambridge, UK: University Press.

Lee, G., and Cole, R. 2003. From a firm-based to a community-based model of knowledge creation: The case of linux kernel development. Organization Science, 14 (6): 633-649.

Lesser, E., and Storck, J. 2001. Communities of practice and organizational performance. IBM Systems Journal, 40 (4): 831-841.

Liu, X., and White, S. 2001. Comparing innovation systems: A perspective and application to China's transitional context. Research Policy, 30 (7): 1091-1114.

Lundvall, B.A. 1992. National systems of innovation: Towards a theory of innovation and interactive learning. London: Pinter. 
Lynn, L., Reddy, L., and Aram J. D. 1996. Linking technology and institutions: The innovation community framework. Research Policy, 25 (1): 91-106.

Malerba, F. 2002. Sectoral systems of innovation and production. Research Policy, 31 (2): $247-264$.

Malerba, F., and Orsenigo, L. 2000. Knowledge, innovative activities and industry evolution. Industrial and Corporate change, 9: 289-314.

Mockus, A., Fielding, R, and Herbsleb, J. 2002. A case study of open source software development: The apache server. ACM Transactions on software engineering and methodology, 11 (3): 309-346.

Nahapiet, J., and Ghoshal, S. 1998. Social capital, intellectual capital and the organizational advantage. Academy of Management Review, 23 (2): 242-266.

Nakakoji, K., Yamamoto, Y., Nishinaka, Y., Kishida, K., and Yunwen, Y. 2002. Evolution patterns of open source software systems and communities. Proceedings of the international workshop on principles of software evolution: 19-20.

Nelson, R. R. 1993. National innovation systems: A comparative analysis. Oxford, UK: University Press. 
Ohmae, K. 1993. The end of the nation state: How region state harnesses the prosperity of the global economy. New York: Free Press McMillan.

Raymond, E. 1999. The Cathedral and the Bazaar. Cambridge, Massachusetts: O'Reilly and Associates.

Saint-Onge, H., and Wallace, D. 2003. Leveraging communities of practice for strategic advantage. Burlington, Massachusetts: Butterworth Heinemann.

Saxenian, A. 1994. Regional advantage: Culture and Competition in Silicon Valley and Route 128. Cambridge, MA: Harvard University Press.

Shane, S., and Ulrich, K.T. 2004. Sectoral innovation, product development and entrepreneurship in management science. Management Science, 50 (2): 133-144.

Smith, M. 2004. Voices from the WELL: The logic of the virtual commons. Unpublished doctoral dissertation, University of California, Berkeley.

Storck, J., and Hill, P. 2000. Knowledge diffusion through "strategic communities". Sloan Management Review, 41 (2): 63-75.

Stringer, E. (ed.) 1997. Community-based ethnography. Mahwah, New Jersey: Lawrence Erlbaum Associates Publishers. 
Sturmer, M. 2005. Open source community building. Unpublished master dissertation, University of Berne, Berne.

Van Wendel de Joode, R., de Bruijn, J.A., and M.J.G. van Eeten. 2002. "Protecting the Virtual Commons". URL:

http://dlc.dlib.indiana.edu/archive/00001075/00/Protecting the Virtual Commons.pdf (accessed on November 23, 2005).

Von Hippel, E. and von Krogh, G. 2003. Open source software and the privatecollective innovation model: Issues for organization science. Organization Science, 14 (2): 209-223.

Wenger, E. 1998. Communities of practice. Cambridge: Cambridge University Press.

Wenger, E. 1999. Communities of practice: Learning, meaning and identity. Cambridge, UK: University Press.

Wenger, E. 2000. Communities of practice and social learning system. Organization articles, 7 (2): 225-246.

West, J. 2003. How open is open enough: Melding proprietary and open source platform strategies. Research Policy, 32 (2): 1259-1285.

Wolcott, H. 1995. The art of fieldwork. Walnut Creek, California: Altamira Press. 
Xu, J., and Madey, G. 2004. "Exploration of the open source software community", URL:

http://www.casos.cs.cmu.edu/events/conferences/2004/2004_proceedings/XuJin1.pdf (accessed on June 13, 2005). 